\title{
Foreign Affairs Cases: The Need for a Mandatory Certification Procedure
}

\author{
[The district court's erroneous decision in Goldwater v. Carter] poses a \\ "serious problem" for newly opened U.S.-Chinese diplomatic relations. \\ A Washington spokesman for the \\ People's Republic of China ${ }^{1}$
}

The American judiciary has long recognized that it should leave foreign affairs matters to the political branches of government. ${ }^{2}$ The courts have expressed this understanding through the use of the political question doctrine, extreme judicial deference to executive and legislative decisions concerning war and related military matters, sovereign immunity, the Act of State doctrine, and a narrow standard of review for decisions concerning immigration and naturalization. These doctrines, which might be termed judicial nonintervention doctrines, call for less judicial inquiry mto actions of the executive and legislative branches in foreign than in domestic affairs.

The results of this judicial deference are evident. For example, the Supreme Court has never declared a treaty provision to be unconstitutional. ${ }^{3}$ Also, courts have read expansively the President's constitutional role as Commander in Chief of the Armed Forces, ${ }^{4}$ permitting

1. China May Cut Ties Over Pact, State Dept. Says, Wash. Post, Oct. 20, 1979, at A14, col. 6. See also Wash. Star, Oct. 21, 1979, at A3, col. 3: "'l'm sorry to see such an important foreign policy matter thrown in the air and doubts thrown on it by the courts.' [Senate Majority Leader] Byrd said: 'I hope the [PRC] knows that this does not reflect the mood of the Senate.' "But see Chinese Seem Unruffed by U.S. Court Decision on Accord with Taiwan, Wash. Post, Oct. 20, 1979, at Al4, col. 5.

2. See, e.g., Techt v. Hughes, 229 N.Y. 222, 247, 128 N.E. 185, 193 (Cardozo, J.) (few precepts for judges in many kinds of foreign affairs cases), cert. denied, 254 U.S. 643 (1920).

3. L. Henkin, Foreign Affairs and the Constitution 137 (1972). The courts have invalidated one executive agreement, however. United States v. Guy W. Capps, Inc., 204 F.2d 655 (4th Cir. 1953). The court voided an executive agreement with Canada that potatoes imported from Canada not be used for "table stock" because Congress had not authorized the executive agreeinent and it contravened provisions of a statute directily on point. $I d$. at 658 . The insigniflcant foreign policy implications of the executive agreement in Capps probably limit its precedential force.

4. U.S. Const. art. II, § 2, cl. I. See, e.g., United States v. Levy, 39 C.M.R. 672 (1968); United States v. Johnson, 38 C.M.R. 44 (1967); United States v. Samas, 37 C.M.R. 708 (1967). These cases before the United States Court of Military Appeals involved challenges to the conflict in Vietnam, and illustrate that a court faced with similar foreign affairs cases may adopt different approaches in denying relief. In Samas, the court-martial rejected a defense based on the illegality of the conflict, holding that it was legal. Id. at 709. This judgment "on the inerits" was reached, however, by way of a perfunctory foreign affairs/great deference to the political branches/no independent judicial inquiry analysis. In Levy and Johnson, the courts invoked the 
the President free rein in war and in foreign "police actions."5

In the last decade, soune foreign affairs nonintervention doctrines have been weakened. For exaunple, Congress has enacted a significant statutory exception to the doctrine of sovereign immunity. ${ }^{6}$ Two recent cases, however, suggest a strengthening of these doctrines. In Goldwater v. Carter $^{7}$ twenty-four Meunbers of Congress challenged the President's exercise of the United States right to terminate the Taiwan Mutual Defense Treaty. In Narenji $\nu$. Civilett $i^{8}$ Iranians holding student visas challenged an Executive regulation that singled them out for immigration checks. In both cases, the district courts incorrectly reached the merits of the allegations, only to be reversed on appeal, with the appellate courts dismissing the actions on judicial nonintervention grounds.

The ultimate decisions in Narenji and Goldwater make plain that the federal courts should not have inquired into the foreign affairs mat-

political question doctrine to hold that the legality of the conflict was nonjusticiable. 39 C.M.R. at 677; 38 C.M.R. at 45. The effect in all three cases was the same: The defendants had no grounds for challenging their orders to serve in Vietnam.

5. In the afternath of the lengthy "police action" in Vietnam, throughout which Congress appropriated funds and conscripted young men to serve in Southeast Asia but never formally declared war, Congress in 1973 asserted its authority to participate in decisions to engage in hostilities abroad by passing the War Powers Resolution, 50 U.S.C. $\$ \$ 1541-1548$ (1976). This legislation requires the President "in every possible instance . . . [to] consult with Congress before introducing United States Armed Forces into hostilities or into situations where immment imvolvement in hostilities is clearly indicated by the circumstances." Id. $\$ 1542$.

Whether, in the face of a ueed for swift military reaction, that Act alters the interaction of Congress and the President in any meaningful way is unclear. It apparently did not in the case of the Mayagllez mcident. See Wicker, Raising Some Mayagüez Questions, N.Y. Times, May 16, 1975, at 37, col. 2 (uselessness of requirement that President consult Congress). But cf. Ford Scores Limit on War Powers, N.Y. Times, Apr. 12, 1977, at 14, col. 4 (ex-President Ford argued that the Act is a nuisance for the President and should be "reconsidered"). Nor did the Act restrict President Carter in the attempt to rescue hostages in Iran by military helicopter. After the rescue attempt failed, Senator Frank Church, chairman of the Senate Foreign Reiations Committee, "criticiz[ed] the President for lack of consultation with Congress." Wash. Post, Apr. 26, 1980, at A8, col. 4.

6. While the Foreign Sovereign Immunities Act (FSIA) of 1976, 28 U.S.C. $\$ \S 1602-1611$ (1976), generally provides foreign states sovereign immumity from jurisdiction of United States courts, the Act provides several exceptions from immunity, including id. $\$ 1605$ (a)(2), which provides that a foreign state shall not be immune in any case "in which the action is based upon a commercial aetivity carried on in the United States by the foreign state . . . " One purpose in enacting the FSIA was to reduce the foreign policy implications of immumity determinations by transferring thein from the executive branch to the judicial. Sugarman v. Aeromexico, Inc., 626 F.2d 270 (3d Cir. 1980). Since the FSIA's transfer of immunity determinations to the judiciary represents the political branches' determination that the judiciary's decisions of this type of case will not conflict with any prior determinations of a pohtical branch, see note $62 \mathrm{infra}$, the nonintervention doctrines do not apply.

7. 481 F. Supp. 949 (D.D.C. Oct. 17, 1979) [heremafter cited as Goldwater I], rev'd per curiam, 617 F.2d 697 (D.C. Cir. Nov. 30, 1979) (en banc) [hereinafter cited as Goldwater II], vacated and remanded, 444 U.S. 996 (Dec. 13, 1979) [heremafter cited as Goldwater III].

8. 481 F. Supp. 1132 (D.D.C. Dec. 11, 1979), rev'd, 617 F.2d 745 (D.C. Cir. Dec. 27, 1979), cert. denied, 100 S. Ct. 2928 (May 19, 1980). 
ters at the core of those cases. ${ }^{9}$ Yet none of the opinions in those cases suggested any means by which district courts could consistently avoid an initial erroneous decision to hear a foreign affairs case or to inquire into a foreign affairs issue. In order to avoid such erroneous decisions, this Comment proposes that Congress enact a statute requiring that where the government nonfrivolously asserts that a case or issue in a district court involves foreign affairs, the court certify that case or issue to the court of appeals for consideration of whether a judicial nonintervention doctrine should be apphed, and the case disinissed or the issue not inquired into.

This Comment argues that the current handling of foreign affairs issues and cases at the district court level is inadequate, and that the suggested procedure would substantially reduce the dangers presented by this problem. The focus of this Comment is more procedural than substantive; it accepts the foreign affairs nonintervention doctrines and their contours as a given. Simce their goal of avoiding certam harms to the national interest is undermined by the current lack of safeguards against initial erroneous district court decisions, the Comment proposes an effective means of avoiding those harns. In a sense, however, the Comment goes further. Agreeing that the nonintervention doctrines represent the appropriate judicial role in foreign affairs inatters, it argues that the consistency in the law achieved by the proposal advanced here for mandatory certification of foreign affairs inatters also represents sound policy. ${ }^{10}$ Accordingly, the proposal is not intended to alter current substantive law, but only to modify current procedures so that the substantive law can be faithfully applied.

Part I of this Comment briefly sets out the various judicial nonintervention doctrines and discusses several recent cases involving foreign affairs matters. Part II examines the cases and the doctrines and proposes a policy-oriented conceptualization of the three types of harins to the national imterest that are likely to result from judicial intervention in foreign affairs. Part II then argues that those three types of harns are likely to result from any courtrooin inquiry into foreign affairs matters or judicial second-guessing of the inerits of the challenged actions. Part III describes the doctrinal and institutional impedinients to consistently correct district court determinations of whether to refuse to hear a foreign affairs case or to decline to inquire imto a foreign affairs issue, thus demonstrating the ongoing nature of the

9. See Goldwater III, supra note 7, at 1006 (plurality opinion) ("the political nature of the questions presented should have precluded the lower courts from considering or deciding the merits of the controversy. ....").

10. Cf. Gurfein, Federal Appellate Procedure, 3I REC. N.Y.C. B. 652, 653 (1976) (appellate procedure presents profound questions of policy). 
problem. Part IV sets forth the proposed statute and defends its adoption as the most reasonable response to the dangers presented by improper judicial inquiry into foreign affairs matters.

I

Foreign AFFaIRS CASES

\section{A. Judicial Nonintervention Doctrines}

Historically, the American judiciary has been sensitive to the principle that executive and legislative actions in the field of foreign affairs require substantially greater deference than is proper in domestic affairs. A number of doctrines for judicial nonintervention in that area reflect that sensitivity. These doctrines are generally consistent with the Restatement view that "courts should abstain from any action that might hinder the executive branch . . . in the conduct of foreign relations." " A brief description of five nonintervention doctrines follows and provides the context for the discussion of Goldwater v. Carter and Narenji v. Civiletti.

\section{Sovereign Immunity}

Under the doctrine of sovereign immunity, presently codified im the Foreign Sovereign Immunities Act of $1976,{ }^{12}$ foreign states with "sovereign" status are granted immunity from certain types of suits in the federal courts. ${ }^{13}$ Determination of whether a foreign state should be given sovereign status is in the sole discretion of the pohtical branches, whose decision is conclusive. ${ }^{14}$

\section{Act of State Doctrine}

The Act of State doctrine is a rule of substantive law that United States courts will not imquire imto the legitimacy of an act of a foreign government done within its national borders. Thus, American courts will not attempt to interfere im the internal affairs of a foreign state. A claimant seeking redress in the United States for such an act of a foreign government therefore can rely only on those diplomatic measures that the United States might attempt on his behalf. ${ }^{\text {is }}$

Thus, in cases mvolving the Act of State doctrine, if the Executive

11. Restatement (Second) of Foreign Relations Law of the United States § 41, Comment c (1965).

12. See note 6 supra.

13. See generally Note, The Foreign Sovereign Immunities Act of 1976: Giving the Plaintiff his Day in Court, 46 FordhaM L. Rev. 543, 544-57 (1977).

14. Jones v. United States, 137 U.S. 202, 212 (1890); Banco Nacional de Cuba v. Farr, 383 F.2d 166, 180 (2d Cir. 1967), cert. denied, 390 U.S. 956 (1968).

15. Underhill v. Hernandez, 168 U.S. 250, 252 (1897). 
recognizes a foreign state, a party aggrieved by a governmental-type $\mathrm{act}^{16}$ of that state cannot turn to the American courts for justice. And if the party turns to the Executive in search of a diplomatic solution, the decision whether to intercede for him is as unreviewable as was the determination of recognition. Such judicial nonintervention serves the national interest by furthering effective foreign relations, but only at the expense of shielding private wrongs from a remedy. ${ }^{17}$

Unlike the United States, most civil law countries do not apply the Act of State doctrine to acts contrary to their sense of public order. ${ }^{18}$ The expansive American Act of State doctrine is thus not as much a rule of international law as it is an expression of two convictions held by the American judiciary: first, that it should defer to the executive branch's superior ability to determine which governments should be recognized as states, and second, that its nonexamination of the conduct of recognized governments promotes "the highest considerations of international comity and expediency." 19

\section{Extreme Deference to Military Decisions}

A third doctrine is that of according extreme judicial deference to war and similar military decisions. ${ }^{20}$ The Constitution explicitly grants to Congress ${ }^{21}$ and to the President ${ }^{22}$ responsibility over military matters. Moreover, the courts lack the expertise needed to make military

16. There is a "commercial act" exception to judicial apphication of the Act of State doctrine. See, e.g., International Ass'n of Machinists \& Aerospace Workers v. OPEC, 477 F. Supp. 553, 565 (1979) (discussing 28 U.S.C. § 1605(a)(2) (1976)).

17. First Nat'l City Bank v. Banco Nacional de Cuba, 406 U.S. 759, 769 (1972) (explaining that the doctrine is designed to avoid having courts frustrate the country's foreign policy); see Oetjen v. Central Leather Co., 246 U.S. 297 (1918) (Pancho Villa's seizure of property while a Carranza-appointed general not subject to American judicial process after the United States had recognized the Carranza government, since recognition retroactively made the seizure an Act of State). See also Underhill v. Hernandez, 168 U.S. 250 (1897) (subsequent rccognition of a revolu. tionary government brought its prior acts against an American citizen under the Act of State doctrine).

18. See, e.g., Anglo-Iranian Oil Co. v. S.U.P.O.R. Co., 22 1.L.R. 19 (Court of Venice 1955); Anglo-Iranian Oil Co. v. Idemitsu Kosan Kabushiki Kaisha, 20 1.L.R. 305 (High Court of Tokyo 1953); Indonesian Nationalization Measures Before Foreign Courts, 54 AM. J. INT'L L. 305 (1960) (discussion of and excerpts from opinions of the District Court in Bremen and the Hanseatic Court of Appeals, and the Amsterdam District Court and Appellate Court).

19. Oetjen v. Central Leather Co., 246 U.S. 297, 303-04 (1918).

20. See, e.g., L.P. Steuart \& Bro. v. Bowles, 322 U.S. 398, 405 (1944) (per Douglas, J.) ("in times of war the national interest cannot wait on individual claims to preference"); Holtzman v. Schlesinger, 484 F.2d 1307, 1310 (2d Cir. 1973) (mvasion of Cambodia precisely the type of question involving military and diplomatic expertise that makes the issue political and beyond the competence of the courts), cert. denied, 416 U.S. 936 (1974). See also Owens v. Brown, 455 F. Supp. 291,300 (D.D.C. 1978) (dictum) (military judgments deserve greal deference because civilians are unfamiliar with necessities of military discipline and duty).

21. U.S. CoNST. art. I, \& 8, cl.16.

22. Id. art. II, $\S 2, \mathrm{cl} .1$. 
decisions, ${ }^{23}$ leading to a high level of judicial deference to executive and legislative decisions in that area.

\section{Deference to Immigration and Naturalization Decisions}

The federal courts review with great deference decisions made by the legislative and executive branches regarding immigration and naturalization. ${ }^{24}$ The justification for this narrow standard of review is that these decisions often hinge on relations with foreign powers, and therefore are decisions appropriately left to the pohtical branches. ${ }^{25}$

\section{The Political Question Doctrine}

The political question doctrine ${ }^{26}$ posits that there are certain "issues to be resolved and decisions to be made by the pohitical branches of government and not by the courts."27 The courts have often invoked this doctrine in foreign affairs cases, ${ }^{28}$ usimg it to justify judicial nonin-

23. Gilligan v. Morgan, 413 U.S. 1, 11 (1973).

24. Fiallo v. Bell, 430 U.S. 787, 792 (1977).

25. Mathews v. Diaz, 426 U.S. 67, 81-82 (1976) ("reasons that preclude judicial review of political questions also dictate a narrow standard of review of [political branches'] decisions . . . in the area of immigration and naturalization") (footnote omitted).

26. Under some interpretations, the political question doctrine subsumes each of the other nonintervention doctrines. For example, when in Oetjen v. Central Leather Co., the Court spoke of judicial acceptance of executive recognition of foreign governments, it did so in terms of both the pohitical question and the Act of State doctrines. 246 U.S. 297, 302-03 (1918). See Tigar, Judicial Power, The "Political Question Doctrine," and Foreign Relations, 17 U.C.L.A. L. REv. 1135,1156 (1970). Justice Bremian has apparently concluded that the Act of State doctrine is based on political question concerns. First Nat'l City Bank v. Banco Nacional de Cuba, 406 U.S. 759, 787-89 (1972) (Brennan, J., dissenting). See also note 25 supra.

Some standard references on the political question doctrine are: Field, The Doctrine of Political Questions in the Federal Courts, 8 MiNN. L. REv. 485 (1924); Finkelstem, Judicial Self-Limitation, 37 HaRv. L. Rev. 338 (1924); Finkelstein, Further Notes on Judicial Self-Limitation, 39 Harv. L. Rev. 221 (1925); Frank, Political Questions, in Supreme Court and SUPREME LAw 36 (E. Cahn ed. 1954); Henkin, Is There a "Political Question" Doctrine? 85 YALE L.J. 597 (1976); Scharpf, Judicial Review and the Political Question: A Functional Analysis, 75 YALE L.J. 517 (1966); Tigar, supra, Tollett, Political Questions and the Law, 42 U. DET. L.J. 439 (1965); Weston, Political Questions, 38 HaRv. L. REv. 296 (1925). The articles that appeared after the seminal case of Baker v. Carr, 369 U.S. 186 (1962), are generally more useful than those published previously.

For a critical look at political question doctrine analysis in foreign affairs cases, see Note, The Supreme Court as Arbitrator in the Conflict Between Presidential and Congressional War-Making Powers, 50 B.U. L. Rev. 78, 85-94 (Special Issue, Spring 1970); Cominent, Public Interest Litigation and United States Foreign Policy, 18 HaRv. INT'L L.J. 375, 417 (1977). See also Schwartz \& McCornack, The Justiciability of Legal Objections to the American Military Effort in Vietnam, 46 TEX. L. REv. 1033 (1968).

27. Henkin, supra note 26, at 597.

28. A classic expression of the applicability of the pohitical question doctrine to foreign affairs is in Chicago \& S. Air Lines, Inc. v. Waternnan S.S. Corp., 333 U.S. 103 (1948):

The President ... has available intelligence services whose reports are not and ought not to be published to the world. It would be intolerable that courts, without the relevant imformation, should review and perhaps nullify actions of the Executive taken on information proporly held secret. . . But even if courts could require full disclosure, the 
tervention in deportation cases $^{29}$ and separation of powers cases such as the challenges to the Vietnam conflict ${ }^{30}$ and now the two Chinas problem.

Madison and the other founders of the Republic recognized the compelling importance of a single voice or united front on foreign as opposed to domestic policy. ${ }^{31}$ Although the Court has established that the "checking function"32 of the judiciary is paramount in domestic matters, the "umited front" has consistently prevailed in foreign affairs matters. ${ }^{33}$ Congress has shown a corresponding deference to the Exec-

very nature of executive decisions as to foreign policy is political, not judicial. . . . They are delicate, complex, and involve large elemeuts of prophecy. . . . They are decisions of a kind for which the Judiciary has neither aptitude, facilities nor responsibility . . . .

Id. at 111. See also Hirota v. MacArthur, 338 U.S. 197, 208 (1948) (Douglas, J., concurring).

Of the various types of cases to which the political question doctrine has been applied, foreign affairs cases most require strict judicial nonintervention. Professor Wright has noted that the doctrine's "principal application is to questions of international and domestic law that immediately concern the pohtical or military interactions of the United States with foreign governments . . .." C. WRIGHT, FEDERAL COURTS 52 (3d ed. 1976).

29. See, e.g., Harisiades v. Shaughnessy, 342 U.S. 580, 591 (1952) (political branches had already determimed the way to secure better treatment for aliens; the courts should not work at cross-purposes with that determination).

30. Holtzman v. Schlesinger, 484 F.2d 1307 (2d Cir. 1973), cerl denied, 416 U.S. 936 (1974); Orlando v. Laird, 443 F.2d 1039 (2d Cir.), cert. denied, 404 U.S. 869 (1971).

31. The Federalist No. 42 (J. Madisou).

32. Blasi, The Checking Value in First Amendment Theory, 1977 AM. B. Found. ReseArCH J. 521.

33. See, e.g., cases cited note 28 supra. The need for a "united front" does not mean that there are no checks on the political branches. The "checking function" on the foreign affairs powers of the political branches should be aud is largely political. P. BATOR, P. MishkiN, D. Shapiro \& H. WechSler, Hart \& WeChSLer's The Federal Courts and the Federal SysTEM 233 (2d ed. 1973) (among the salient considerations which contribute to the conclusion that a question is nonjusticiable is "the superiority of political checks as guides to decisions"). There are at least three effective checks on Executive power: the Congress, the electorate, and other nations.

Congress has numerous devices to check executive action in foreign affairs. Most importantly, it has the spending power. For example, the Congress could have checked the President's actions in Vietnam by cutting off the billious of dollars per year needed to finance those actions. For a brief history of the appropriations, see Orlando v. Laird, 443 F.2d 1039, 1042 n.2 (2d Cir.), cerl. denied, 404 U.S. 869 (1971). Congress could also have ended the war by using its power over conscription.

Although Congress for many years did not use its powers to check the Vietnam war, it has been inore aggressive in reviewing presidential action in the area of treaties. The Senate must concur by two-thirds vote in all treaties, and has been by no means a rubber stamp. It may attach amendments or reservations, or it may simply reject a treaty, as it has already done some 60 times. J. Plano \& M. Greenberg, American Polmical Dictionary 410-11 (5th ed. 1979). About $70 \%$ of the nearly 1600 treaties subinitted to the Senate have been approved. Many of those have never been put into force because Senate amendinents or reservations were unacceptable to the President or to the other treaty parties. $7 d$. at 411 . Any congressional exclusion from foreign policy decisions has been inostly by cougressional choice. See Treaties, politics, and the court, Chicago Tribune, Dec. 17, 1979, § 3, at 2, col. 2: "The Congress, in the treaty case, could use its appropriations power to resist President Carter's action. The Senate could have refused to give its consent to the appoimtment of an ambassador to China. Other legislation the President holds dear could have been threatened by legislators."

The Executive must also answer to the people. Marbury v. Madison, 5 U.S. (1 Cranch) 137, 
utive in foreign affairs in the interest of "one voice." 34 In areas such as immigration, in which Congress normally makes the foreign affairs determinations, the courts have proved similarly deferential when judicial review of those determinations has been sought. ${ }^{35}$

\section{B. Goldwater and Narenji}

In two recent cases, federal appellate courts applied judicial nonintervention doctrimes to foreign affairs cases. Both cases were decided incorrectly by the district courts, but were reversed on appeal.

\section{Goldwater v. Carter}

On December 15, 1978, the United States and the People's Republic of China (PRC) announced that they would establish full diplomatic relations on January 1, 1979. ${ }^{36}$ The two nations issued a jomt communique that said, in part, that the PRC is "the sole legal Government of China."37 Agreement with that statement required the United States to exercise its right under the Taiwan Mutual Defense Treaty ${ }^{38}$ to terminate that treaty on one year's notice. ${ }^{39}$ The President gave that notice

165-66 (1803) (President's use of important political powers accountable politically only); Pauling v. McNamara, 331 F.2d 796, 799 (D.C. Cir.), cert. denied, 377 U.S. 933 (1964) (people may remove their elected representatives, but not the federal judiciary). This is more than a mere homily of democratic theory without a practical basis. Foreign affairs and security matters are very high visibility issues with the electorate. Presidents have risen and fallen with popular support both for their foreign policy and for their record of collaboration with Congress on that foreign policy. See, e.g., T. Bailey, A Diplomatic History of the American People 824-25 (8th ed. 1969):

The Republican platform assailed the Democrats for having lost China to the Communists, for having "plunged us into war in Korea without the consent of our citizens through their authorized representatives in the Congress," aud for fighting "without will to victory."

...

Foreign affairs . . . probably proved decisive . . . .

For the most conspicuous time in American history, the party in power was evicted in the midst of piping prosperity.

The two inost importaut issues, according to postelection Gallup polls, that helped elect Eisenhower were corruption and Korea. Id. at 825 n.11.

Finally, there is the constraint, often absent in domestic affairs, of the give-and-take with other countries. The counterforce-diplomatic, military, and commereial-of individual nations and of the community of nations also circumscribes the foreign affairs acts of the pohitical branches.

34. For example, although Congress has refused to adopt the view that it must as a matter of constitutional law enact legislation implementing the international obhigations of the Umited States, it has repeatedly done so. L. HenkIN, supra note 3, at 162.

35. See cases cited notes $24-25$ supra.

36. Nash, Contemporary Practice of the United States Relating to International Law, 73 AM.

J. INT'L L. 277, 277 (1979).

37. Id.

38. 6 U.S.T. 433, T.I.A.S. No. 3178.

39. Nash, supra note 36 , at 278 . 
as of January $1,1979 . .^{40}$

On December 22, 1978, Senator Goldwater and twenty-three other legislators filed suit in federal district court seeking declaratory and injunctive relief to prevent termination of the treaty without either senatorial or congressional consent. After preliminary proceedings, ${ }^{41}$ the court permitted the plamtiffs to air their allegation that President Carter had mismanaged diplomatic negotiations and had usurped the Congressional role in treaty matters. The court determined that the case did not present a political question, ${ }^{42}$ and held that the President could not terminate the treaty without the approval of either two-thirds of the Senate or a majority of both Houses of Congress, in effect enjoining rapprochement with the PRC.

The Court of Appeals for the District of Columbia Circuit, sitting en banc, reversed on the merits. ${ }^{43}$ The Supreme Court vacated that judgment and reinanded the case to the district court with directions to dismiss the complaint. ${ }^{44}$ Four Justices ${ }^{45}$ stated that the case presented a political question, and that the district court should not have heard the case, since it "involve[d] the authority of the President in the conduct of our country's foreign relations and the extent to which the Senate or the Congress is autliorized to negate the action of the President." 46 Two Justices thought the case presented no political question, ${ }^{47}$ and three Justices did not address the issue. ${ }^{48}$ Thus, although the opinions do not

40. Id.

41. On January 18, 1979, Senator Goldwater and 16 other Senators submitted a concurrent resolution stating that the President should not abrogate mutual defense and other security treaties "without the advice and consent of the Senate . . . or the approval of both Houses of Congress." S. Con. Res. 22, 96th Cong., 1st Sess., 125 Cong. REC. 219 (1979). Neither House of Congress took any action on that resolution. On June 6 the district court dismissed the suit, without prejudice, for lack of standing, observing that three resolutions pending in the Senate might resolve the controversy. Goldwater II, 617 F.2d at 701.

The Senate then passed a resolution drafted by Senator Harry Byrd, Jr. stating that "the sense of the Senate [is] that approval of the United States Senate is required to terminate any mutual defense treaty between the United States and another nation." Id. Whether that resolution was to have retroactive effect was unclear. After the resolution passed, Senator Goldwater filed a motion in the district court for alteration or amendment of the June 6 order of dismissal. It was granted, and the case proceeded. Id.

42. Goldwater I, supra note 7, at 956-58.

43. Goldwater I1, supra note 7, at 699.

44. Goldwater III, supra note 7, at 996.

45. Id. at 1002 . Justice Rehnquist was joined by Chief Justice Burger and Justices Stewart and Stevens.

46. Id.

47. Id. at 997-1002 (Powell, J., concurring) (no pohtical question, but case not ripe for review); id. at 1006-07 (Breunan, J., dissenting) (no political question; the Constitution commits the power to recognize foreign governments to the President alone).

48. Justice Marsliall concurred in the result. Id. at 996. Justices Blackmun and White would have set the case for oral argument "on the issue of [its] justiciability" as well as other issues. Id. at 1006. 
delineate clearly the Court's conception of the political question doctrine, they do indicate its continuing vitality.

Although the Supreme Court decision ended the judicial intervention into U.S.-PRC relations, the judiciary had already interfered irrevocably with a major foreign affairs initiative and had initially invalidated it. This high-visibility setback executed by an organ of the American government imperiled the United States fragile rapprocheinent with the PRC. ${ }^{49}$

\section{Narenji v. Civiletti}

In response to the Iramian seizure of more than fifty American hostages in November 1979, the President took a number of nonmilitary actions in order to pressure the Iranian government to release the hostages. $^{50}$ One of these actions was to issue an Executive regulation ${ }^{51}$ requiring all Iranians holding American student visas to report to inimigration or university officials for a determination of whether their immigration papers were in compliance with American law.

In Narenji $v$. Civiletti ${ }^{52}$ several Iramans holding student visas brought suit in the district court, alleging that the regulation was unconstitutional. The district court failed to apply a nonintervention doctrine and, looking into the policy reasons for the regulation, found it to be unconstitutional.

The Court of Appeals for the District of Columbia Circuit unaniinously reversed..$^{53}$ Although the regulation was inipleinented entirely within the United States, the court held that its effect and thrust were clearly foreign and imtergovernmental. The court accepted the Attor-

49. See Administration Seeks to Avoid Taiwan Fallout, Wash. Star, Oct. 19, 1979, at 1, col. 1 (capitol special ed.):

[The administration hopes to avoid] a possible serious setback for Chinese-American relations that could unbalance the triangular relationship between Peking, Moscow and

Washington. ...

..

Solne officials expressed apprehension . . . that a legal defeat for Carter would be

taken abroad as a sign of U.S. weakness and inability to conduct a stable foreign policy.

Deputy Secretary of State Christopher had filed an affidavit stating that judicial interference with the President's action "would disrupt the process of normalization of relations with the People's Republic of China to the detriment of the national interest of the United States. . . . It would at a minimum be a serious setback in U.S. relations with China that could have far-reaching and long-lasting consequences." $I d$.

50. For example, President Carter indefinitely halted purchases of Iranian oil. See, e.g., Wash. Post, Nov. 13, 1979, at A1, col. 1. He also "order[ed] blocked all property and interests in property of the Government of Iran, its instrumentalities and controlled entities and the Central Bank of Iran which are or become subject to the jurisdiction of the United States . . . " Exec. Order No. 12,170, 3 C.F.R. 457 (1980).

51. 8 C.F.R. 214.5 (1980).

52. 481 F. Supp. 1132 (D.D.C. 1979).

53. 617 F.2d 745 (D.C. Cir. 1979), cert. denied, 100 S. Ct. 2928 (1980). 
ney General's view that the regulation was "an element of the language of diplomacy . . . fundamental [to] the President's efforts to resolve the Iranian crisis and to maintam the safety of the American hostages in Tehran."54

Although the appellate decision halted judicial imterference with that aspect of the President's handling of the Iranian hostage crisis, some damage had already been done. The district court had openly questioned and had initially mvalidated a major foreign policy move. Its error, although quickly reversed, had irrevocably added, at the worst possible monient, a contribution from the federal judiciary to Iran's deliberate attempt to humiliate the United States.

\section{Other cases}

Goldwater and Narenji are not unique. District courts have been increasmgly willing to consider and decide sensitive foreign affairs cases im recent years. Many of their decisions have been incorrect. ${ }^{55}$ Considering the gravity of the possible harms from initial erroneous decision in the foreign affairs realm, this frequency of error is cause for concern. Even in the months since the final decisions in Goldwater and Narenji, there has been hittle evidence of district court restraint in foreign affairs matters.

Foreign affairs cases decided or pending after the ultimate decision of Goldwater and Narenji demonstrate the contmuing possibility of district court decisions presenting grave consequences for the effective conduct of foreign affairs. ${ }^{56}$ For example, the decision in Haitian Refu-

54. Id. at 747 .

55. Rosado v. Civiletti, 621 F.2d 1179 (2d Cir.) (exchange of prisoners pursuant to treaty with Mexico) (reversing the district court), cert. denied, 49 U.S.L.W. 3248 (Oct. 6, 1980); Jackalone v. Andrus, No. 79-2359 (D.C. Cir. Nov. 19, 1979) (Iranian demonstrations in front of the White House) (reversing the district court's refusal to grant an injunction); Adams v. Vance, 570 F.2d 950 (D.C. Cir. 1977) (mandatory injunction against the Seeretary of State, ordering him to vote a certain way in an international commission) (incorrectly decided by the district court); $c f$. Edwards v. Carter, 580 F.2d 1055 (D.C. Cir.) (Panama Canal Treaty) (district court dismissed plaintiffs for lack of standing) (affirmed on the inerits), cert. denied, 436 U.S. 907 (1978); American Jewish Cong. v. Vance, 575 F.2d 939 (D.C. Cir. 1978) (district court dismissed as pohtical question) (affirmed on other grounds); International Ass'n of Machimists \& Aerospace Workers v. OPEC, 477 F. Supp. 553 (C.D. Cal. 1979) (antitrust suit) (deeided against plaimtifis on the merits, but only after four days of hearings airing grievances agamst OPEC). But see Pfeifer v. United States Bureau of Prisons, 615 F.2d 873 (9th Cir. 1980) (exchange of prisoners pursuant to treaty with Mexico).

56. Presently, there are many pending claims against frozen lranian assets in this country. The following cases were pending on appeal as of August 1980: American Int'l Group, Ine. v. Islamic Republic of Iran, No. 80-1779 (D.C. Cir.) (action for just compensation for nationalized minority interests in Iranian insurance compamies) (appeal from preliminary injunction enjoining Iran from removing assets froin the United States and from order granting plaimtiff American imsurance coinpanies partial summary judgment on issue of liability); Charles T. Main Int'l, Inc. v. Khuzestan Water \& Power Auth., No. 80-I027 (1st Cir.) (action for fees for professional services 
gee Center v. Civiletti, ${ }^{57}$ decided after Goldwater and Narenji, shows no judicial deference to the political branches. In that case, the district court permitted a lengthy airing, over the objections of the State Department, of grievances about political conditions in Haiti, a nation friendly to the United States. The only way that the complainants, Haitian refugees, could remain in this country was for them to convince the court that they liad left Haiti due to political persecution, a course that required them to use the official forum of the courtroom to paint political conditions in Haiti in as reprehensible a tone as possible. The court reached the merits of the case and invalidated the Government's foreign affairs decision that inost Haitian refugees are fleeing abject poverty, not political persecution. The court brushed aside an Immigration and Naturalization Service inemorandum stating that the Haitians generally are economic ratler than political refugees, and that a decision to receive them would encourage a deluge of the world's poor to come to tlie Umited States. ${ }^{58}$

II

\section{The Types of Harms Threatened by Judicial INTERVENTION IN Foreign AfFaIRs CASES}

Deference to the foreign affairs determinations of the legislative and executive branches, often exercised under the name of the political question doctrine, was already judicial practice when the Supreme

rendered to Iranian electrification projects) (appeal from preliminary injunction enjoining Iran from disposing of, encumbering, or removing assets); New Eng. Merchants Nat'l Bank v. Iran Power Generation and Transmission Co., No. 80-1071 (1st Cir.) (action for declaratory judgment and damages for failure to pay promissory notes) (appeal from preliminary injunction enjoining Iran from disposing of, encumbering, or removing assets); Inperial Iranian Air Force v. Behring Int'l, Inc., Nos. 79-1784 \& 79-2529 (3d Cir.) (action for payment for commercial freight forwardimg services rendered to Iranian Air Force) (appeal from orders authorizing prejudgment attachment of defendant's property); Electromic Data Syss. Corp. v. Social Sec. Org. of the Gov't of Iran, Nos. 79-2641 \& 80-1641 (5th Cir.) (action for damages for breach of contract and for failure to ensure safety of plaintiff's employees in Iran) (appeal from same type of injunction as in Main, supra, and from final judgment awarding damages, interest, attorney's fees and costs to plaintiff). See also E-Systems, Inc. v. Islamic Republic of Iran, 491 F. Supp. 1294 (N.D. Tex. 1980) (prejudgment attachment of blocked account denied).

In many of the Frozen Assets cases, the State Department has written to the court to express its view that "any action taken at this time in these cases could have serious repercussions for the conduct of foreign policy ...." For instance, in a suit in the Southern District of New York involving 75 claims on the fund by American banks on the basis of alleged unpaid debts and loans, the Department urged a 60-day stay of all proceedings for foreign policy reasons, and the district court complied. UPI Dispatch, Jan. 8, 1980, 12:51 AES (emphasis added) (on file with the California Law Review).

57. 49 U.S.L.W. 2065 (S.D. Fla. July 2, 1980).

58. Id. "Unless overturned on appeal, the ruling means the Haitians mnst be granted new, unrushed hearings on their claims to political asylum. That process, says one lawyer for the Haitians, could take '10 to 15 years.' " U.S. Anxious to Weave New Threads into Immigration Net, Christian Science Monitor, July 8, 1980, at 4, col. 3. 
Court decided Baker v. Carr ${ }^{59}$ in 1962. Although it involved the political question doctrine as applied to domestic matters, Baker v. Carr is the seminal case for the doctrine generally. In that case, the Supreme Court delineated six analytical strands underlymg the doctrine, ${ }^{60}$ two

59. 369 U.S. 186 (1962). This Comment does not enter the debate whether the political question doctrine is constitutionally based, Wechsler, Toward Neutral Principles of Constitutional Law, 73 HARV. L. REv. 1, 7-9 (1959); Tigar, supra note 26, at 1135, prudentially based, Finkelstein, Judical Self-Limitation, supra note 26, at 344-45, or both, A. BICKEL, THE LEAST DANGEROus BRANCH 184 (1962); Scharpf, supra note 26, at 566. See also L. HeNkIN, supra note 3, at 213. Instead, it analyzes the strands advanced in Baker $v$. Carr in order to construct a policy-oriented frainework for identifying when the political question or other judicial nonintervention doctrine should be applied to foreign affairs cases.

60. The six factors explicitly inentioned in Baker v. Carr are:

[A] textually demonstrable constitutional commitinent of the issue to a coordinate political department; or a lack of judicially discoverable and manageable standards for resolving it; or the impossibility of deciding without an initial policy determination of a kind clearly for nonjudicial discretion; or the impossibility of a court's undertaking independent resolution without expressing lack of the respect due coordinate branches of government; or an unusual need for unquestioning adherence to a political decision already unade; or the potentiality of embarrassment from multifarious pronouncements by various departments on one question.

369 U.S. at 217.

1. Embarrassment. The analysis in the text treats this harm. See text accompanying notes 61-70 infra.

2. Inappropriateness of a Policy Determination by the Judiciary. This characterization represents, but is less inclusive than, the cluster of harms from the judiciary's operating at cross-purposes with the political branches' initiatives or actions in the foreign affairs area. Sce text accompanyimg notes 71-74 infra.

3. Need for Unquestioning Adherence. The need for judicial adherence is equivalent to the need to avoid the three types of harms discussed at text accompanying notes 61-88 infra. The "unquestioning" language is troubling, since the courts have recognized that some foreign affairs unatters present difficult trade-offs between civil liberties and effective foreign policy. Thus the judicial nonintervention doctrines have not been, and should not be, regarded as invitations to ultimate unquestioning adherence. Were concentration camps with gas chambers, $c f$. Korematsu v. United States, 323 U.S. 214 (1944) (Japanese wartine relocation case), to be set up in this country in the name of effective foreign policy, it is unthinkable that the Supreme Court would not intervene because "pohtical questions" were involved.

4. Textual Commilment. Judicial decision of inatters textually coininitted in the Constitution to another branch would usurp the legislative and executive roles. It would therefore be a violation of the constitutionally mandated separation of powers. To the extent that the textual commitınent problem affects the United States position abroad or its foreign relations, it falls into one of the three harns considered in this Comment.

5. Lack of Due Respect. This characterization is irrelevant to foreign affairs, except to the extent that it produces embarrassinent abroad or is smultaneously an instance of judicial working at cross-purposes.

6. Lack of Judicial Standards. This characterization subsumes two problems. There must be discoverable standards (means to obtain and evaluate evidence) so that the case can be decided. There must also be manageable standards (means to formulate and enforce an order) so that the inatter can be put to rest.

While in general it may be more difficult to obtain evidence from abroad than from within the country, this without more is no reason to invoke a foreign affairs nonintervention doctrine. If the success of $A$ 's suit agamst $B$ rehes on the deposition of $C$, a foreigner who lives abroad, $A$ 's failure to obtain the deposition should cause him to lose on the merits. Like thousands of other plaintiffs, he simply would have failed to prove his case. See Tigar, supra note 26, at 1165. Invocation of the political question doctrine for an evidentiary reason ineans that even if the party 
of which apply to foreign affairs cases. The Court stated that political question determinations in the foreign affairs area

seem invariably to show a discriminating analysis of the particular question posed, in terms of the history of its inanagement by the pohitical branches, of its susceptibility to judicial handling in the light of its nature and posture in the specific case, and of the possible consequences of judicial action. ${ }^{61}$

Thus, judicial action in foreign affairs cases may have serious adverse consequences. This Comment presents the three types of harmful consequences that may result from judicial imtervention in foreign

could obtain evidence from abroad to prove his claim (or establish his defense), the court would not consider that evidence. See generally Comment, supra note 26 , at $418-19 \mathrm{n} .163$. To the extent that evidentiary problems hinder the conduct of foreign affairs, it is because they cause one of the three types of harms. The concern is not that a party before an American court may fail to prove a claim based on foreign evidence; it is that he may succeed. The political branches have already determined, lowever, that certain types of evidence from abroad should not be pursued, subjected to discovery, or lieard in the American courts. To allow trafficking in such evidence, then, for the purpose of prevailing in an American court would be a judicial contradiction of the other branches' policy determination (a cross-purpose harm), would einbarrass the nation, or would force disclosure of state secrets. See, e.g., United States v. Sisson, 294 F. Supp. 511, 515 (D. Mass. 1968).

As to lack of evaluative standards for such foreign evidence as is received, that argument is largely a makeweight. For instance, in 1966, Judge Friendly had no difficulty in determining that the Cold War, exacerbated by United States involveinent in Vietnain, establislıed the existence of a national einergency sufficient to triggcr $\S 5(\mathrm{~b})(1)$ of the Trading with the Enemy Act, 50 App. U.S.C. $§ 5$ (1976). Sardimo v. Federal Reserve Bank, 361 F.2d 106, 109 (2d Cir.), cert. denied, 385 U.S. 898 (1966). And in litigation concerning insurance policies, courts have not had difficulty determining the existence of a state of war. See, e.g., Stanbery v. Aetna Life Ins. Co., 26 N.J. Super. 498, 503, 98 A.2d 134, 137 (1953) (Korean War); Hamilton v. McClaughry, 136 F. 445, 451 (C.C.D. Kan. 1905) (Boxer Rebellion); Note, supra note 26, at 81 n.11.

The second possible gloss on "discoverable and manageable standards for resolving the controversy" is that the phrase refers to remedy. This gloss "is not the mark of a pohtical question," but merely "restate[s] the principle of ripeness and the equity principle that the cliancellor cannot intervene where the dispute will not permit the entry of a judicially-manageable mandatory decree." Tigar, supra note 26 , at 1164.

It could, llowever, be argued that the real problem is not in formulating the injunction, but ratler in enforcing it, and that the high probability of defiance of an order enjoining foreignaffairs-related activities urges invocation of the political question or other nonintervention doctrine. However, this argument does not bear scrutiny as an independent ground for judicial nonintervention in a foreign affairs matter. First, it las been in the domestic rather than the foreign affairs area that there liave been serious risks of defiance of court orders. See Note, supra note 26, at 98 . By contrast, in the Steel Seizure case, Youngstown Slieet \& Tube Co. v. Sawyer, 343 U.S. 579 (1952), President Truman made clear that he would abide by whatever determination the Supreine Court made on the validity of seizurc, whicl was arguably related to the Korean War.

Second, the possibility that a party would resist or defy a judicial decision does not justify a foreign affairs exception to judicial review. Cf. Nixon v. Sirica, 487 F.2d 700, 708 (D.C. Cir. 1973) (en banc) (Presidential compliance with a subpoena, if otherwise justiciable, will be decided even if the judiciary cannot enforce it).

In sum, there is no harm to the national interest froin judicial resolution of foreign affairs cases independent of the embarrassment or cross-purposes harms, and the separate problem of state secrets disclosure.

61. 369 U.S. at 211-12. 
affairs cases: embarrassment, cross-purposes, and the disclosure of state secrets.

\section{A. The Three Harms}

\section{Embarrassment Harms}

If an American court decides a foreign affairs matter in a way fundamentally inconsistent with the political branches' prior ${ }^{62}$ determination of the appropriate response, the Umited States might be embarrassed in the eyes both of the nations receiving the conflicting signals and the world generally. ${ }^{63}$ The nation or nations mvolved might perceive those signals as signs of confusion, suggestimg American weakness and unrehability, or as "double-crossing," suggesting bad faith. The principal danger of this harm is the likelihood that such a perception would weaken the Umited States overall bargaining position m intergovernmental relations.

As Judge Leventhal noted in Adams v. Vance:64 "This country's interests in regard to foreign affairs and international agreements may depend on the symbolic significance to other countries of various stances . . . . Courts are not im a position to exercise a judgment that is fully sensitive to these matters."65 The Supreme Court has stated explicitly that courts should avoid probing into foreign expropriations largely to prevent embarrassment harms. In Banco Nacional de Cuba v. Sabbatino, 66 for example, the Court stated that "however impartial" the American tribunal may be, its decision "might increase any affront," and that "[r]elations with third countries which have engaged in similar expropriations would not be immune froin effect."67 Many cases have emphasized avoidance of embarrassment as a primcipal reason for judicial abstention in foreign affairs cases. ${ }^{68}$

62. If the actions and pronouncements of a political brancli lave not yet determined (or suggested) an American response contrary to the relief sought from the courts, then court action could not be seen as intervention and the courts should not invoke a foreign affairs nonintervention doctrine. See, e.g., Baker v. Carr, 369 U.S. at 211-13 (judicial intervention not barred when executive action not conclusive) (citing examples).

63. Cf. L. HENKIN, supra note 3, at 162 (Congress implements the international obligations made by the President partly because of an "unwillingness to make the American system appear undependable and ludicrous").

64. 570 F.2d 950 (D.C. Cir. 1977).

65. Id. at 955. See also Baker v. Carr, 369 U.S. at 217; L. Henkin, supra note 3, at 162; Scharpf, supra note 26, at 582.

66. 376 U.S. 398 (1964).

67. Id. at 432 .

68. See, e.g., Chicago \& S. Air Lines, Inc. v. Waterman S.S. Corp., 333 U.S. 103, 111 (1948) (Presidential revision of Civil Aeronautics Board order awarding a foreign air route not reviewable because of foreign affairs considerations); Mexico v. Hoffinan, 324 U.S. 30, 35 (1945) (notion underlying sovereign immunity cases is desire not to embarrass the executive branch); Braniff Airways, Inc. v. CAB [Clicago-Montreal], 581 F.2d 846 (D.C. Cir. 1978) (same as Chicago \& S., 
Beside Narenji, perhaps the best recent example of the potential for embarrassment harm is presented by the Vietnam Conflict cases. Judicial invalidation of an aspect of America's military efforts im Southeast Asia would have produced a substantial embarrassment harm abroad, furnishing a rich propaganda harvest to the United States enemies and its less direct Cold War adversaries. Another danger would have been that nations unfamiliar with our system of judicial review ${ }^{69}$ might liave read the decision as a signal of a lack of resolve or of an imminent change im policy. ${ }^{70}$

\section{Cross-Purposes Harms}

The cross-purposes harm has a more direct impact on a particular foreign affairs policy than the embarrassment harm. If the judiciary's ultimate decision of a foreign affairs matter were to contradict, undo, or block the acts of the political branches, great tangible harms would ensue from the branches' working at cross-purposes. ${ }^{71}$

supra); Wulfsohn v. Russian Socialist Federated Soviet Republic, 234 N.Y. 372, 138 N.E. 24 (1923) (Cardozo, J.) (review of foreign affairs decision would embarrass the poiitical branches).

69. Cf. Closing Lafayette Square, Wasl. Post, Nov. 21, 1979, at A16, col. 1 (emphasis added):

The possibility is clear that the Iranians holding Americans hostage in the embassy there, not understanding what demonstrations in a democracy are all about, would interpret any demonstration so close to the White House as one sponsored by the government-and base their actions toward their prisoners on totally erroneous assumptions.

70. There are two additional poimts on the embarrassment harm. First, although adinitting that there is an embarrassment harm, some argue that the best way to avoid it is not by judicial deference to foreign affairs acts of the political branches, but by scrupulous scrntiny of those acts. See, e.g., R. Falk, The Role of Domestic Courts in the International Legal Order (1964). In Goldwater II, Judge MacKinnon argued that the PRC reaction was irrelevant and that the court "should not offend [the] lasting value of our constititional scheme in the pursuit of momentary political ascendancy." 617 F.2d at 737 (MacKinnon, J., dissenting).

Even assuming that this position is correct, it would still not argue against this Comment's proposed statute. The proposed statute is not concerned with what the judicial branch does. It does not advocate removing from the judiciary, or altering the judiciary's uitimate view of, foreign affairs matters. It is concerned only with reducing erroneous initial decisions. It is hard to see how removal of a forum for erroneous official action can in any formulation embarrass the nation in its intergovernmental relations.

Second, this proposal is limited to foreign affairs matters. Domestic affairs, even if of immense foreign interest, are not subject to the proposed statute. Cf. Time, Inc. v. Firestone, 424 U.S. 448, 454 (1976) (public controversy different from controversies of interest to the public). Although acquittal or nonprosecution of the "Wilmington 10" might have improved world public opinion of the United States, see Wash. Post, Dec. 15, 1979, at A 10, col. I, their trial on allegedly trumped-up charges in a North Carolima town was not a foreign affairs case. Nor was the trial of Ethel and Julius Rosenberg. See Rosenberg v. United States, 346 U.S. 273 (1953).

71. For example, the government has to be able to make decisions that affect other countries. Perhaps the inost candid statement of this irreducible principle of imternational relations was made by ex-Secretary of State Henry Kissinger:

Somewhere, somehow, the United States must show that it is capable of rewarding a friend or penalizing an opponent. It must be made clear . . . that our allies benefit from association with us and our enemies suffer.

It is a simpleminded proposition perhaps, but for a great power it is the prerequisite, indeed the definition of an effective foreign policy. 
The OPEC suit ${ }^{72}$ is a good example of a case presenting the possibility of such a harm. The political branches had determined, or suggested the determination, that the United States government should not take on the OPEC nations' price-fixing practices. Had the district court permitted the plaintiff unions to subject the OPEC nations to an antitrust and conspiracy suit in an American federal court, it would have been working at cross-purposes with the political branches' deterinination. ${ }^{73}$ Assuning that one of the purposes of the political branches' decision was that better relations with the OPEC nations might result in an increase in energy supphes or lower oil prices, a court ruling that OPEC was violating the Ainerican antitrust laws would have accoinplished nothing worthwhile, and might have caused a decrease in energy supphes or increase in oil prices.

Leaving the foreign policy decisionmaking process open to such shifts in position would cause both einbarrassment and cross-purposes harnis to the United States. Embarrassment harms are typically harms to the country's reputation, while cross-purposes harms are generally characterized by a governmental mability to react to world events in a swift, effective, and unified manner. ${ }^{74}$

\section{Disclosure of State Secrets Harms}

A third type of harm of special concern in foreign affairs cases is disclosure of sensitive information about United States activities abroad or United States relations with other governments. For exam-

S.F. Chronicle, Apr. 11, 1980, at 21, col. 6.

72. International Ass'n of Machinists \& Aerospace Workers v. OPEC, 477 F. Supp. 553 (C.D. Cal. 1979). Nevertheless, the court permitted four days of hearings, providing a government forum for the plaintiffs' attempt to show that OPEC "price-fixing" "contributed to . . . a recession in the United States." S.F. Chronicle, Aug. 24, 1979, at 16, col. 1.

73. See also Holtzman v. Schlesinger, 484 F.2d 1307 (2d Cir. 1973) (court expressly recognized that to order that Cambodia not be harmed, after the political determination to conduct bombing in that nation, could cause serious harm, since the court could not evaluate and competently decide the inilitary and diplonnatic issues involved), cert. denied, 416 U.S. 936 (1974).

74. Judicial inquiry into the procedures of the political branches' foreign affairs determinations "would, indeed, destroy the flexibility of action which the executive and legislative branches have in dealing with other sovereigns." Orlando v. Laird; 443 F.2d 1039, 1043 (2d Cir.), cert. denied, 404 U.S. 869 (1971). Cf., Goldwater III, supra note 7, at 997-1002 (Powell, J., concurring). Justice Powell suggested that he would readily apply the political question doctrine were the Court "asked to decide . . . whether a treaty required the President to order troops into a foreign country." Id. at 999 . He would not, however, apply the political question doctrine to a case involving conflicting interpretations of the forms and procedures that the political branches must use in their interactions in response to foreign affairs probleins, as was the case in Goldwater.

This distinction, lowever, seems to give little weight to the harms enumerated here, which can as readily occur from judicial intervention into the nature of the political branclies' accommodations in fashioning their response, as into the response itself. See, e.g., Orlando v. Laird, 443 F.2d 1039, 1043 (2d Cir.) (Inethod of congressional collaboration is a political question), cert. denied, 404 U.S. 869 (1971). 
ple, in United States v. Reynolds, ${ }^{75}$ an Air Force B-29 had crashed while testing secret electronic equipment. The widows of three civilian observers who had died in the crash sued the Government and moved to discover evidence that the Air Force had concerning the accident. The Supreine Court upheld the Air Force's claim that the evidence, although concededly relevant to the action, was privileged and therefore could be withheld from production, even for in camera inspection. Although the Court drew an analogy to the attorney-client and selfincrimination privileges in upholding the Air Force's claim, the Court's decision seems actually to have hinged on its view that it could not, in 1953, "escape judicial notice that this is a time of vigorous preparation for national defense." 76

Thus, Reynolds appears to be another in the line of judicial decisions deferring to the political branches in foreign affairs. Its deference to the Executive's determmation that this information should remam secret hinged to a substantial degree on the foreign affairs uses to which the airborne military liardware being tested would be put, ${ }^{77}$ and on the Court's tacit recognition of the role that military competition with the Soviet Union and the Comnunist bloc played in the United States intergovernmental relations at the time.

The Feres doctrime ${ }^{78}$ attempts to avoid the same type of harms as was presented in Reynolds. Under that doctrine, a secret agent's superiors are immune from suit under the Federal Tort Claims Act ${ }^{79}$ if the agent's injuries are incurred "incident to service." 80 A recent case invoking the Feres doctrime is Sigler v. LeVan. ${ }^{81}$ Sigler had worked for about ten years as a "double agent," identifying Russian agents by selling them often-fabricated American military secrets. After he failed a lie detector test at a debriefing, he was sent to Fort Meade, where he committed suicide. His widow and daughter sued for damages. The court dismissed the action and rejected the plaimtiffs' contention that the Feres doctrine is inapplicable in cases involving "intentional constitutional violations in a noncombat setting," 82 even though it recognized that this conclusion would sometimes lead to "unconscionable results." "83

\footnotetext{
75. 345 U.S. 1 (1953).

76. Id. at 10 .

77. "[A]ir power is one of the most potent weapons in our scheme of defense ... IId.

78. Feres v. United States, 340 U.S. 135 (1950).

79. 28 U.S.C. $\$ \S 2671-2680$ (1976).

80. 340 U.S. at 146.

81. 485 F. Supp. 185 (D. Md. 1980).

82. Id. at 191 (citing Thornwell v. United States, 471 F. Supp. 344, 348 (D.D.C. 1979)).

83. 485 F. Supp. at 191 (quoting Thornwell v. United States, 471 F. Supp. at 348 n.1).
} 
The Freedom of Information Act, ${ }^{84}$ which generally requires government agencies to disclose documents requested by members of the public, also recognizes that the executive branch must be permitted to keep secret sensitive military and diplomatic information. ${ }^{85}$ The Act expressly exempts from disclosure matters that are "specifically authorized . . . by an Executive order to be kept secret in the interest of national defense or foreign policy." 86 Thus, the state secrets evidentiary privilege seeks to avoid some or all of the harms to the national interest that the political question and other foreign affairs nonintervention doctrines seek to avoid. ${ }^{87}$

\section{B. Similar Harms Result from Any Erroneous Airing or Court Decision}

The three types of harms discussed above do not occur only from an ultimate erroneous decision of a foreign affairs case or issue. Although the harms are generally not as great, they occur from any erroneous decision in a foreign affairs case, even one that is subsequently reversed. This section examines the problein of an initial erroneous decision-later "corrected" on appeal-to hear a case, grant injunctive relief, or decide the merits.

\section{Embarrassment Harms}

A courtroom hearing on the merits of a foreign affairs matter can cause embarrassment harms no matter how the case ultimately is decided. Embarrassment harms are caused as soon as an organ of the American government-a federal court-permits the wisdoin and manner of the negotiations, horse-trading, arm-twisting, cajolery, threats, and accommodations between the pohtical branches and other nations to be questioned in an official public forum. That an organ of the United States Government is conducting such an inquiry at all may persuade foreign governments that the Umited States Governinent is disorganized or confused. Thus, there is often "the imperative need of unity at home for dealing abroad."88 Although apphication of the polit-

84. 5 U.S.C. $\$ 552$ (1976 \& Supp. III 1979).

85. Developments in the Law-The National Security Interest and Civil Liberties, 85 HARv. L. REV. 1130, I218 (1972).

86. 5 U.S.C. $\$ 552(\mathrm{~b})(1)(A)(1976)$.

87. See Developments in the Law-The National Security Interest and Civil Liberties, supra note 85, at 1226: "[T] he balancing of substantial competing interests in security and disclosure involves an essentially political judgment as to what course would be best for the nation."

In England, the decision whether the privilege for official information exists is for a political minister. See 8 J. Wigmore, Evidence $\$ 2379$ (g), at 808 (McNaughton rev. ed. 1961).

88. Weston, supra note 26, at 319. "[A]ny intrusion into [foreign affairs] inatters such as the recognition of foreign governments might iinperil the amicable relations between governinents 
ical question doctrine should "prevent a party from airing an issue"89 involving foreign affairs, a district court's failure to apply a nonintervention doctrine quickly and correctly will often result in judicial imquiry into the merits of the case. Such an inquiry will often have, for many of the foreign governments and peoples involved, all the charm that an inquiry conducted by an inferior Iranian tribunal into prior Iranian-American relations would have for the American government and people. ${ }^{90}$

A district court's dismissal of a foreign affairs case after trial would reduce these harins only shightly. ${ }^{91}$ Or, in potentially the most danaging situation, the court might decide against the action taken by the political branches, thus tacitly or exphicitly criticizing the government's handling of a foreign affairs matter. Ultimate reversal may negate the legal effect of the trial court's error, but much of the negative propaganda or other elnbarrassment effect caused by the decision would remain.

The creation of embarrassment harms by imitial erroneous decision is exemphified in the handling of Senator Goldwater's Taiwan challenge. The initial erroneous decision seems very likely to have left the PRC - and America's current and potential allies-with the impression of confusion, indecisiveness, or unrehability on the part of the government. ${ }^{92}$ This impression might outhe the ultimate disposition of the Goldwater case.

The embarrassment harins caused by the Narenji decision are perhaps clearer. One of the principal causes of the current Iranian-American tension is Iran's dehberate attempt to humiliate the United States. ${ }^{93}$ The initial erroneous decision in Narenji aided this attempt by allowing

and vex the peace of nations.' " Note, supra note 26, at 92 (quoting Oetjen v. Central Leather Co., 246 U.S. 297, 304 (1918)).

89. Tigar, supra note 26 , at 1135 .

90. See U.S. Warns Tehran on "Parading" of Hostages Before Any Tribunal, N.Y. Times, Dec. 11, 1979, at A1, col. 4: "The White House warned Iran today that the United States would regard the 'parading' of American hostages before an Iranian-appointed international tribuual of inquiry with the same gravity as it would view any trial of the Americans."

In Decenber 1979, when judicial proceedings against the hostages seemed an imminent possibihity, the Administration warned Iran repeatedly of the "grave risks" of the hostages "being put on trial or brought before a tribunal" regardless of what the ultimate outcome might be. NBC Nightly News broadcast, Dec. 18, 1979, reprinted in White House Press Summary, Dec. 19, 1979 (on file with the California Law Review).

91. It could increase such harms in some cases. For exaniple, a pohitical question determination after a trial full of revelations about the conduct of foreign affairs could cause still further einbarrassment harms by appearing to other nations to be a "cover-up."

92. Thus, the danage done to the national image by the initial decision in Goldwater could also be seen as a cross-purposes harm. For the "true" cross-purposes harm of the decision, see text accompanying note 104 infra.

93. Interview with Henry Kissinger, NBC News (aircd Apr. 25, 1980) (transcript on file with the California Law Review). 
the United States Government to be portrayed as an oppressor of Iranian students.

In sum, the need to avoid the aggravated embarrassment harms to intergovernmental relations that may occur from any judicial airing of or initial erroneous decision concerning foreign affairs matters justifies strict judicial respect for the finahty of the political branches' decisionmakmg ${ }^{94}$ in the foreign affairs area, a respect that would be unjustified in the domestic realm.

\section{Cross-Purposes Harms}

In the case of reviewable district court decisions airing, secondguessing, or contradictimg foreign policy acts, cross-purposes harins might seem to cause less difficulty than embarrassment harms. For example, the appellate court can stay the lower court decision pending appeal. ${ }^{95}$ An attempt to distinguish cases involving predommantly cross-purposes harms from those imvolving predominantly embarrassment harms, however, would be misguided for three reasons. First, the cross-purposes harms in foreign affairs cases will often be difficult to separate from the embarrassment harms, ${ }^{96}$ and there is nothing to be gained by forcing the district court to try to do so. Second, the current system of stays and related procedures to delay the implementation of a district court's decree, pending appeal, can be cumbersome and inefficient. ${ }^{97}$ Third, in inany foreign affairs cases, any hearing, court process, or initial erroneous decision itself causes cross-purposes harin. This happens when the political branches do not want any norınal judicial consideration of a sensitive foreign affairs issue. The classic example of such a situation was suggested in Banco Nacional de Cuba v. Sabbatino ${ }^{98}$ _the "incongruity of judicial 'recogmition,' by permitting suit, of a government not recognized by the Executive." 99

That example, however, is only one of several types of cross-pur-

94. See Frank, supra note 26 , at 38 .

95. See, e.g., United States v. Washington Post Co., 446 F.2d 1327, 1329 (D.C. Cir.) (per curiam) (en banc) (Pentagon Papers case) (stay granted after district court denial of preliminary injunction agamst disclosure, and continued pending government's petition for certiorari to Supreme Court), aff sub nom. New York Times Co. v. United States, 403 U.S. 713 (1971).

96. See note 92 and accompanying text supra.

97. For example, in Narenji, the Government petitioned the D.C. Circuit for an "emergency stay" to delay enforcement of the district court's ruling. Baltinore Sun, Dec. 13, 1979, at A2, col. 2. Nevertheless, as a direct result of the initial erroneous decision in the case, the Attorney General was forced to alter the timetable chosen by the political branches as the most appropriate response to the fast-1noving hostage crisis by having to extend the deadline for checking visas more than two weeks. Civiletri Extends to Dec. 31 Iran Visa-Review Deadline, Wash. Star, Dec. 20, 1979, at A8, col. 2.

98. 376 U.S. 398 (1964).

99. Id. at $410-11$. 
poses harms that can occur from an initial erroneous decision. ${ }^{100} \mathrm{~A}$ more substantial threat of cross-purposes harms caused by any hearing or decision on the merits is presented by the Iranian Frozen Assets cases. ${ }^{101}$

Any court action at this particularly sensitive time (whether favorable or unfavorable to lran) can have adverse consequences on the President's efforts to resolve the problems of the United States with Iran. The Iranians are likely to view court action as U.S. Government action and consequently as a signal of the U.S. Government's attitudes and positions. At this critical juncture in U.S.-Iranian relationships, it is important that there be no unintended signals which the Iranians might construe as representing the policy or position of the U.S. Government. ${ }^{102}$

Goldwater I might have caused specific cross-purposes harms. First, the PRC's decades-long mistrust of the American government, a sworn military and ideological enemy for more than a generation, might have been renewed. As a result, PRC receptivity to developing governmental, commercial, and cultural ties might have cooled. Second, the court's erroneous decision might have led the PRC leadership to conclude that there was greater popular and governmental opposition to the substantive foreign policy decision that triggered Goldwater than actually existed. ${ }^{103}$ Finally, this conclusion might have led to a possibly irreversible dimimution in the comparative imfluence of PRC officials favoring closer relations with the United States. ${ }^{104}$

100. See, e.g., Ex parte Peru, 318 U.S. 578 (1943) (prejudgment seizure of an ally's merchant ship, although political branclies had established a contrary policy); Occidental of Umm al Qaywayn, Inc. v. A Certain Cargo of Petroleum Laden Aboard the Tanker Dauntless Colocotronis, 577 F.2d 1196 (5th Cir. 1978) (cross-purposes harm would occur from taking jurisdiction of case involving Middle Eastern border dispute, simce State Department was taking neutral stance), cert. denied, 442 U.S. 928 (1979); Adams v. Vance, 570 F.2d 950 (D.C. Cir. 1977) (mandatory injunctions against Secretary of State different from those against other government officials not involved in foreign affairs); NORML v. United States, 452 F. Supp. 1226, 1234-35 (D.D.C. 1978) (nnandatory injunction sought by plaintiff directing defendants to persuade Mexico to stop herbicide spraying program presented political question).

101. See cases cited note 56 supra.

102. Affidavit of G. William Miller, Secretary of the Treasury, July 29, 1980, submitted in Citibank v. Iran, No. C79-3542 (pending in N.D. Cal.). The district court accepted the Governinent's view and stayed for three months all further proceedings in 20 suits in order "to help resolve the U.S. hostage crisis in Iran." Wasl. Post, Nov. 14, 1980, at A16, col. 1.

103. See, e.g., Editorial, The China Treaty Challenge, Wash. Star, Oct. 19, 1979, at 10, col. 2 (the adıninistration had actually chosen "with few misgivings" to recognize the PRC).

104. The Goldwater plaintiffs sought to show that Vice-Premier Deng, contrary to the public official position he had taken, had stated in private talks that immediate termination of the Mutual Defense Treaty with Taiwan was not a precondition to normalization. Plamtiffs submitted declarations from persons to whoin Deng had allegedly "personally conveyed" that view. BRIEF SUBMitTed for Senator Barry Goldwater in Goldwater Against Carter, 125 CONG. ReC. S4839, at $\$ 4841$ (daily ed. April 26, 1979).

Sinilarly, the district court decision in Narenji may have helped sustain the hard-liners' hold on power in Iran and possibly added to the length of the crisis. 


\section{Disclosure of State Secrets Cases}

Once court processes have forced the disclosure of state secrets ${ }^{105}$ they cannot by any amount of favorable or expedited appeals be hushed up. All that the law can do to protect agamst a district court erroneously permitting disclosure is to permit appeal before a discovery order is put into effect or other disclosure is compelled.

In camera inspection ${ }^{106}$ does not completely resolve the problems created by an initial erroneous decision. Even if held ex parte and with thorough security precautions, the procedure may not be adequate. ${ }^{107}$

The political branches, particularly Congress, have recently disfavored in camera inspection as a way to verify and assess the foreign affairs sensitivity of alleged foreign affairs materials. For example, in United States v. American Telephone \& Telegraph Co. ${ }^{108}$ thc executive branch had ordered warrantless wiretaps, purportedly for national security reasons. Congress subpoenaed the telephone company's records of those wiretaps as part of its inquiry into whether they had actually been used solely for national security purposes. At the urging of the executive branch, the telephone company resisted the subpoena. The two branches attempted to reach a comproinise, with the executive branch finally suggesting in cainera verification procedures. Congress rejected such procedures on the ground that courts were "not equipped to carry these out properly." ${ }^{109}$ Also, when Congress passed legislation to require a judicial warrant in foreign intelligence cases, and thus ensure judicial review of government wiretapping and electronic bugging in such cases, it did not rely on in camera examination by federal judges and inagistrates. Instead, it set up a new secret federal court. ${ }^{110}$ Furthermore, the Executive, following the mandates of effective diplomacy, often inakes foreign governments pronises that on their face appear to preclude in camera inspection."11

105. In this situation there will often be an overlap of some state secrets cases with crosspurposes cases. See, e.g., Harrington v. Bush, 553 F.2d 190, 201 n.50 (D.C. Cir. 1977) (plaintiff Congressman attempting to get more information concerning $\mathrm{ClA}$ funding than Congress wished him to have, threatened both types of harms).

106. See, e.g., United States v. Nixon, 418 U.S. 683, 714-16 (1974).

107. In camera inspection involves the movement of sensitive information, its storage in chambers where security precautions will rarely be as tight as in the material's usual place of storage (e.g., the Pentagon or CIA headquarters), and possible exposure to persons who lack security clearance (e.g., law clerks). The provision of tight security during the transit of the evidence to be inspected, and a requirement that it be delivered for same-day inspection by the judge alone, could obviate some but not all of these security problems.

108. 567 F.2d 121 (D.C. Cir. 1977).

109. Id. at $125,130$.

110. See Foreign Intelhgence Surveillance Act of 1978, 50 U.S.C. $\$ \S 1801-1811$ (Supp. II 1978). See also A Secret Court OX's Buggings, S.F. Chronicle, Apr. 25, 1980, at 12, col. 1.

111. See, e.g., Anderson, Treasury's Well-Kept Arab Secrets, Wash. Post, July 9, 1980, at D8, col. 4: "To encourage the Saudi Arabians to invest their windfall billions in the United States, 


\section{III}

\section{DOCTRINAL AND INSTITUTIONAL IMPEDIMENTS TO Correct Decision of Foreign AfFairs Cases}

The three types of harms discussed above can be caused by any normal judicial consideration of foreign affairs issues and cases. Given the gravity of the harms that might be caused by erroneous district court decisions in the area of foreign affairs, it might seem that only judicial neghigence could produce such a decision. Were that the case, this Comment would simply highlight those harms and urge district court judges to take them more seriously. The roots of the problem, however, are much more complex, involving both the foreign affairs nonintervention doctrines-each confusing in its own right-and certam institutional factors.

\section{A. Doctrinal Problems}

\section{Nonintervention Doctrines Do Not Apply to All Foreign Affairs Cases}

The decision whether a foreign affairs case is nonjusticiable or an issue nonreviewable depends only partially on its foreign affairs nature. However, neither Baker v. Carr nor later cases have specified an operative definition of a foreign affairs case or issue or the weight that should be given to a finding that a case or issue predominantly involves foreign affairs. ${ }^{112}$ Thus, a court asked to decide whether a noninterven-

President Ford's [administration] promised that their financial holdings in this country would be kept inviolably secret."

112. The confusion of domestic and foreign affairs political questions is a related problem. Current analysis does not distinguish between foreign affairs and domestic cases even though it is generally accepted that decision of political questions in foreign affairs cases causes different harms than does their decision in domestic cases. C. WRIGHr, supra note 28, at 52 . For example, the Goldwater III plurality relied on Coleman v. Miller, 307 U.S. 433 (1939), but that case was entirely domestic. In Coleman, Congress had proposed a Child Labor Amendment in order to overcome the effect of the Court's holding in Hammer v. Dagenhart, 247 U.S. 251 (1918). Kansas' ratification was challenged as invalid, but the Court ruled the issue nonjusticiable. Coleman is easily distmguishable from Goldwater: it had nothing to do with foreign affairs. Moreover, in Coleman there was a coinpelling reason for judicial abstention: Were the Court to intervene in the only constitutional process by which Congress, the states, and the people can overturn the Court's constitutional interpretations-by amendment of the Constitution-it would exceed "the inlerent linits of the power of judicial review in a democratic polity." Scharpf, supra note 26, at 588. See Goldwater III, supra note 7, at 536 n.2 (Powell, J., concurring) (suggesting the same idea). The political question holding in Coleman was a constitutional decision inandated by separation of powers principles. Indeed, it might be that after Baker v. Carr, 369 U.S. 186 (1962) (Court took role im a political case textually committed to a state), and Powell v. McCormack, 395 U.S. 486 (1969) (Court took role in a pohtical case textually committed to Congress), Coleman stands only for the proposition that the Court will abstain froin ruling on inatters imvolving the only constitutional process by which the people and their elected representatives can overturn constitutionally-based Court rulings.

Thus, Goldwater $I I I$, with its failure to produce a majority on any of the views advanced and 
tion doctrine is applicable has hittle guidance on how to balance the need to abstain froin the foreign affairs aspects of the case against the inclination to decide the individual rights questions that may be presented in the case.

\section{Confusion with the Standing Doctrine}

A recurrent source of doctrinal confusion is the interplay of the political question and other nonintervention doctrines with the law of standing. Standing is a coinplex doctrine $e^{113}$ based on both constitutional and prudential considerations, ${ }^{114}$ as to which there is a vast literature $^{115}$ but few helpful rules for hard cases. For purposes of this Comment, the important aspect of the standing requirement is not its precise definition, but the fact that it is less stringent than before. ${ }^{116}$ The result is increased access to the federal courts.

For example, the courts have recently permitted Members of Congress who cannot gain legislative majorities sufficient to achieve their goals to air their minority position in court. ${ }^{117}$ These plaintiffs must convince the courts that as a matter of constitutional law a certain procedure should have been followed in the consideration of their positions-a procedure either between the Houses of Congress, ${ }^{118}$ or between one House of Congress and the Executive, ${ }^{119}$ or between both Houses of Congress and the Executive. ${ }^{120}$ The problems in such cases tend to be twofold. First, these are not cases in which a inajority of Congress has approved the lawsuit. ${ }^{121}$ Instead, the plaintiffs are legisla-

the failure of the plurality to distinguish foreign from donestic affairs, did hittle to help a district court determine which foreign affairs cases call for judicial nonintervention and which do not. See also C. WRIGHT, supra note 28, at 52 (no definite standard for determining whether particular case presents pohtical question).

113. See, e.g., Flast v. Cohen, 392 U.S. 83, 129 (1968) (Harlan, J., dissenting) (standing is a "word game played by secret rules").

114. See, e.g., Warth v. Seldin, 422 U.S. 490, 498 (1975).

115. See Note, Standing to Sue for Members of Congress, 83 YALE L.J. 1665, 1665 n.1 (1974) (collecting a sampling of law review articles and treatises).

116. United States v. Richardson, 418 U.S. 166, 188 (1974) (Powell, J., concurring).

117. See, e.g., Edwards v. Carter, 580 F.2d 1055 (D.C. Cir.) (challenge to Panama Canal Treaty), cert. denied, 436 U.S. 907 (1978); Holtzman v. Schlesinger, 484 F.2d 1307 (2d Cir. 1973) (challenge to Caunbodian boinbing), cert. denied, 416 U.S. 936 (1974); Goldwater I, supra note 7, at 949.

118. Compare Edwards v. Carter, 580 F.2d 1055 (D.C. Cir.) (challenge to Panaina Canal Treaty that would have given the House a voice), cert. denied, 436 U.S. 907 (1978), with Byrd Urges Senate to Vote an End to Taiwan Treaty, Wash. Post, Oct. 21, 1979, at A30, col. 1 (Senate Majority Leader Byrd stating a Senate vote could resolve the Goldwater problem, as the House had no role).

119. E.g., Goldwater v. Carter, 444 U.S. 996 (1979).

120. E.g., Holtzman v. Schlesinger, 484 F.2d 1307 (2d Cir. 1973) (challenge to Cambodian bounbing), cert. denied, 416 U.S. 936 (1974).

121. See, e.g., United States v. American Tel. \& Tel. Co., 551 F.2d 384, 391 (D.C. Cir. 1976) (House sought to compel production of records of Executive-ordered phone taps); Senate Select 
tors who have failed to convince their colleagues that adherence to the desired procedure was worth fighting for politically. ${ }^{122}$ Thus, the plaintiffs arrive in federal court having lost in the pohtical arena. ${ }^{123}$ Second, challenges concerning foreign affairs decisions, although couched in purely procedural terms, almost invariably require for their disposition a judicial inquiry into the "judicial wilderness"124 of foreign affairs policies. ${ }^{125}$

These problems sliould be treated differently. The first is a trne question of standing. Since recent law tends toward the view that legislators should receive "no special consideration in the standing inquiry," 126 denial of standing to legislative losers is often required. Indeed, they may deserve less consideration on standing than other plaintiffs. ${ }^{127}$ The second problem, however, often requires application of the political question doctrime. ${ }^{128}$ Goldwater is an example of just how complicated the standing inquiry can become when it is intermixed with foreign affairs nonintervention issues. ${ }^{129}$ Absent a clear delineation of these doctrimes, some procedural remedy is required.

\section{B. Institutional Problems}

In addition to the doctrinal problems discussed above, institutional probleins also make it unlikely that district courts will consistently avoid the harns of initial erroneous decisions on foreign affairs matters by correctly applying the political question and other judicial nonintervention doctrines. Two important institutional problems are that foreign affairs cases do not call for the use of three-judge district courts, and that judicial temperament tends to inake it difficult for judges to treat foreign affairs cases correctly.

Comm. on Presidential Campaign Activities v. Nixon, 498 F.2d 725, 727 (D.C. Cir. 1974) (Senate authorized suit to enforce a subpoena duces tecum for production of tapes of conversations between the President and his aides).

122. The majority opinion in Goldwater $I I$ poimted out that if Congress is aroused about adherence to certain procedures but is nevertheless ignored, "it has its arsenal of weapons, as previous Chief Exccutives have on occasion been sharply reminded." 617 F.2d at 709.

123. See, e.g., Harrington v. Bush, 553 F.2d 190, 215 (D.C. Cir. 1977) (plaintiff Congressman sought "the relief which his colleagues have refused him").

124. Goldwater II, supra note 7, at 716 (Wright, J., concurring).

125. See Comment, supra note 26 , at 405-06.

126. Reuss v. Balles, 584 F.2d 461, 466 (D.C. Cir.), cert. denied, 439 U.S. 997 (1978); see Harrington v. Bush, 553 F.2d 190, 204 (D.C. Cir. 1977).

127. Goldwater II, supra note 7 , at 710 (Wright, J., concurring).

128. See, e.g., Holtzman v. Schlesinger, 484 F.2d 1307, 1309 (2d Cir. 1973), cert. denied, 416 U.S. 936 (1974).

129. Compare Goldwater II, supra note 7, at 702 (a mmority of Senators have standing), with id. at 709-16 (Wright, J., concurring) (his lack of standing argument similar to a ripeness or pohtical question analysis); Goldwater III, supra note 7, at 997-98 (Powell, J., concurring) (his lack of ripeness argument similar to a standing analysis). 


\section{Three-Judge District Courts}

In 1910 Congress provided for the use of three-judge district courts in certain kinds of cases. ${ }^{130}$ In the aftermath of Ex parte Young ${ }^{131}$ and faced with "the practice of inany Federal judges of [too readily] granting interlocutory injunctions ... or . . . temporary restraining orders ex parte," 132 Congress sought by means of the three-judge district court mechanism to afford a procedural protection agamst the "improvident .. . dooun" of a single federal judge mvalidatimg a state legislative policy. ${ }^{133}$ As a sponsor of the legislation stated, it protected government programs, particularly state revenue and regulatory programs, from the temporary paralysis sometimes caused by the action of "one little federal judge."134 In 1946, Congress extended the use of three-judge district courts to include challenges to Acts of Congress. ${ }^{135}$

Subsequently, statutes and court decisions limited the jurisdiction of the federal courts to review state laws, and the use of three-judge district courts caused such procedural difficulties that its benefits were no longer clear. ${ }^{136}$ In 1976 Congress followed the advice of many scholars and jurists and abolished three-judge district courts m most cases. It retamed them only where expressly required by an Act of Congress or in cases involving the apportioninent of congressional districts or statewide legislative bodies. ${ }^{137}$ Despite the many administrative and procedural problems that these courts had caused, Congress retamed them for reapportionment cases because it felt that reapportionment issues are of such importance that three-judge courts should liear them in the first mstance. ${ }^{138}$

The general abolition of three-judge courts, combimed with Congress' failure to extend the coverage of such courts to cases involving executive actions, has had its effect on foreign affairs cases. In many sucl cases the plamtiff seeks injunctive relief from the enforcement of a federal statute or Executive regulation. ${ }^{139}$ Such a case is entitled only to a one-judge court, while cases of similar importance are entitled to

130. Act of June 18, 1910, ch. 309, $\$ 17,36$ Stat. 557 (1910) (amended and repealed, Act of Aug. 12, 1976, 90 Stat. 1119 (1976)).

131. 209 U.S. 123 (1908).

132. [1976] U.S. CODE CONG. \& AD. NEwS 1988, 1989 (recounting the legislative history of the original $1910 \mathrm{Act}$ ).

133. See Phillips v. United States, 312 U.S. 246, 251 (1941).

134. 45 CONG. REC. 7256 (1910) (remarks of Senator Overman).

135. Act of June 25, 1948, ch. 646, § 2282, 62 Stat. 968 (1948) (repealed, Act of Aug. 12, 1976,

90 Stat. 119 (1976)).

136. [1976] U.S. CoDE CoNG. \& AD. NEwS 1988, 1996.

137. Id.

138. Id.

139. See, e.g., Narenji, 617 F.2d 745; Haitian Refugee Center v. Civiletti, 49 U.S.L.W. 2065 (S.D. Fla, July 2, 1980). 
three-judge courts. ${ }^{140}$

\section{Judicial Temperament}

The Supreme Court ${ }^{141}$ has repeatedly agreed with the view that "courts are not equipped or competent to make foreign policy, or to judge the impact of their rulings in occasional cases on the vital concerns of the nation." 142 If judicial unfamiliarity with, and lack of expertise $\mathrm{m}$, foreign affairs were the only "temperament" factors of note, the danger of erroneous decision of foreign affairs cases might not be significant, since great judicial deference could be expected. However, the courts also have great expertise in and solicitude for the proteetion of individual rights. ${ }^{143}$ This imclination may be a significant factor in the production of erroneous mitial decisions im foreign affairs cases.

\section{IV \\ A Procedural Remedy-Mandatory Certification TO THE COURTS OF APPEALS}

Present procedures are madequate to avoid the harms caused by erroneous judicial consideration of foreign affairs matters. Appeals from district courts generally are limited to "final judgments" or "decisions." 144 None of the exceptions to this rule is applicable im this situation. For example, Ryan rule treatment, under which a ruling may be immediately appealed if denial of such rehef "would render impossible

140. Despite the system's faults, Congress retained the use of three-judge district courts for certain classes of important cases, rather than permit initial decision by a single district court judge. Congress might agree, once the special harms to the national interest from initial erroneous decision of foreign affairs cases are brought to its attention, that those harms, though different than those of apportionment cases, see 28 U.S.C. $\$ 2284$ (1976), civil rights cases, see 42 U.S.C. $\$ \S 2000 \mathrm{a}-5(\mathrm{~b}), 2000 \mathrm{e}-6(\mathrm{~b})$ (1976), and voting cases, see id. $\$ \$ 1971(\mathrm{~g}), 1973 \mathrm{~b}(\mathrm{a}), 1973 \mathrm{c}, 1973 \mathrm{~h}(\mathrm{c})$ (1976), are at least as worth avoiding as the possible harms in those cases.

141. See, e.g., Banco Nacional de Cuba v. Sabbatino, 376 U.S. 398, 431-32 (1964).

142. Henkin, The Foreign Affairs Power of the Federal Courts: Sabbatino, 64 Colum. L. REv. 805,832 (1964).

143. See, e.g., J. Choper, Judiclal Review and the National Political Process-A Functional Reconsideration of the Role of the Supreme Court 80-128 (1980) (Court best at protecting individual rights).

In the aftermath of the Watergate scandal, the judiciary is less apt to defer to the Executive. See Barbash, The Explosion of Judicial Power, S.F. Chronicle, Feb. 10, 1980, Sunday World section, at 24 , col. 1 , stating that

There is no longer any reservation in the district courts about the presidency.

"Yes, I think that's true," said U.S. District Court Judge Oliver Gasch, who decided the Taiwan treaty case, when asked if he nay have been emboldened by the [Watergate] tapes decision. "It may very well have been. I felt the issue should be inet," he said. "As a judge, I felt this was my problem."

This change is most pronounced in cases relating to foreign policy.

144. 28 U.S.C. $\$ 1291$ (1976). 
any review whatsoever of an individual's claims,"145 is not applicable. Nor can the decision to try a foreign affairs case be immediately appealed as a collateral order. ${ }^{146}$ Mandamus is not available. ${ }^{147}$ Expe-

145. United States v. Ryan, 402 U.S. 530, 533 (1971). This exception was applied in United States v. Nixon, 418 U.S. 683 (1974).

In the "unique" circumstances of Nixon, the Court held that it would have been "peculiarly inappropriate" to force the President, as his sole means of securing review, to resist the order to turn over tapes in his possession and then challenge the resulting contempt citation. Id. at 690-92. The determmation that a foreign affairs case should not be aired or decided on the merits would not render review "impossible" in the Ryan sense, nor would it be "peculiarly inappropriate" in the Nixon sense.

146. In order to alleviate the hardship caused by the final judgment rule, the judiciary has created the fiction that a certam class of orders is final for purposes of 28 U.S.C. $\$ 1291$ (1976), "even though further proceedings remain to resolve fully the dispute between the parties." Note, Appealability in the Federal Courts, 75 Harv. L. Rev. 351,364 (1961). The two leading cases in this area, however, involve a trial court cancellation of deeds and immediate transfer of real property, Forgay v. Conrad, 47 U.S. (6 How.) 200 (1848), and a trial court refusal to condition plaintiff's right to maintain a derivative action on the posting of a bond, Cohen v. Beneficial Indus. Loan Corp., 337 U.S. 541 (1949).

Although it might be argued that the hearing and decision of a foreign affairs case forces the government to incur irreparable harm, there are at least three significant distinctions that suggest that such a decision is not an immediately reviewable "collateral order." First, the harms of embarrassment, cross-purposes, and state secrets disclosure are often speculative and somewhat hard to show, while the harms from the Forgay and Cohen orders were definite and tangible. In Cohen, for example, "immediate appeal was necessary to assure the defendants that the bond could be collected should they win on the merits." Note, supra, at 364.

Second, foreign affairs nonintervention doctrines, rather than being "collateral" to the issues left pending before the court, may often be closely connected to the issue still pending-the merits of the dispute. That is, if a balancing of the merits is necessary, the same foreign affairs harms that urged application of a nonintervention doctrme will be a factor in that balancing.

Third, a "collateral" order must be so related to the case that "if erroneous, [the collateral orderl would not be grounds for reversing the final judgment," $i d$. at 365 , and thus "final" for $\S 1291$ purposes. That is not the case with determinations on the applicability of foreign affairs nonintervention doctrines.

147. 28 U.S.C. $\$ 1651$ (a) (1976), the All Writs Statute, authorizes federal courts to "issue all writs necessary or appropriate in aid of their respective jurisdictions and agreeable to the usages and principles of Iaw." Under this provision, "the courts of appeals will on occasion issue the extraordinary writs of mandamus, prohibition, and certiorari to review action taken by district judges." Note, supra note 146, at 375 . For purposes of this discussion, the relevance of $\S 1651$ (a) writs is that the appellate courts have frequently issued them "to prevent a trial judge from ... hearing a case after erroneously finding jurisdiction over the subject matter or the parties." Id. This unay appear to be good authority for the use of mandamus to compel the district court not to hear or decide a case on the merits, at least for those cases in which a foreign affairs nonintervention doctrime would deprive the court of jurisdiction. Nevertheless, sueh a solution to the unique probleıns of foreign affairs cases would be quite unsatisfactory.

First, the appellate court is unlikely to issue the writ if jurisdiction is doubtful or depends on a question of fact. Id. at 375 n.216. Second, mandamus has not been traditionally reserved for those situations im which the consequences of the suit have been extraordinarily momentous, but rather for those in which the trial judge's mishandling of the case was extraordinary. Thus, mandamus is used primcipally to correct a gross abuse of discretion or improper conduct; it is the means for overriding judicial abuse. Schlagenhauf v. Holder, 379 U.S. 104, 110 (1964). Mandainus thus is not an appropriate remedy for the type of problem addressed in this Comment. See generally Note, Supervisory and Advisory Mandamus Under the All Writs Act, 86 HARV. L. REv. 595 (1973). 
dited appeals and stays are not sufficiently effective to prevent erroneous judicial hearing of foreign affairs matters. ${ }^{148}$ Nor are voluntary certification procedures adequate to prevent the harms that often occur from such a hearing. ${ }^{149}$

148. Procedures such as expedited appeals and stays may be somewhat helpful in dealing with the problem addressed in this Comment, but do not significantly prevent the embarrassment, cross-purposes, or disclosure harms that occur froin any such airing.

As to harms froun an initial erroneous decision of the merits, stays and expedited appeals substantially avoid many cross-purposes harms, since if the trial order is stayed, then the judiciary will not, at cross-purposes with the goals of the political branches, order or enjoin their acts until there has been appellate review.

However, stays and expedited appeals will have little impact on the embarrassment harms of many initial erroneous decisions. Of course, some embarrassment harms will be of an ongoing nature; in those cases a stay of the order or its early reversal might dispel the perception that the United States government is confused, disorganized, or duphitous. As desirable as that is, it is insufficient. Likewise, stays and expedited appeals would not suffice in the situation in which an initial erroneous decision in a foreign affairs case leads to compulsion of the United States government, foreign governments, or other foreign entities to turn over data. It might, in a given case, be sufficient to stay a district court order permitting discovery or compelling production of such data, see, e.g., United States v. Nixon, 418 U.S. 683, 689 (1974) (district court stayed its order compelling in camera inspection of materials alleged to be protected by executive privilege pending appellate review, provided such review was speedily sought), but inclusion of cases of this type under the proposed statute is better tailored to avoiding substantial harms to the effective conduct of foreign affairs. See Note, Jurisdiction and Procedure-Discovery-Party Unable to Comply with Discovery Order Which Contravenes Foreign Nondisclosure Law Is Not in Contempt of Court, 11 VAND. J. TRANSNAT'L L. 351, 359 (1978) (international discovery problems require diplomatic, not judicial, resolution).

In sum, stays, see note 95 supra, and expedited appeals, see, e.g., Edwards v. Carter, 580 F.2d 1055, 1056 \& n.2 (D.C. Cir.) (Panama Canal Treaty) (decided by the appellate court only days after the lower court decision), cert. denied, 436 U.S. 907 (1978), have been used and should be used in cases of the type discussed here. However, they do not ineet the underlying problem of the harms caused by any airing or initial erroneous decision of a foreign affairs matter.

I49. 28 U.S.C. $\$ 1292($ b) (1976) provides that:

When a district judge, in making in a civil action an order not otherwise appealable under this section, shall be of the opinion that such order involves a controlling question of law as to which there is substantial ground for difference of opimion and that an immediate appeal from the order may materially advance the ultimate termination of the litigation, he shall so state in writing in such order.

Voluntary certification is not sufficient to avoid the harms of incorrectly decided foreign affairs cases-although it has been used effectively in a variety of cases, see, e.g., Malamud v. Sinclair Oil Corp., 52I F.2d 1142 (6th Cir. 1975) (standing); Calvin v. Conhisk, 520 F.2d 1, 4 (7th Cir. 1975) (police department internal procedures); Higgins v. Board of Educ., 395 F. Supp. 444 (W.D. Mich. 1973) (busing); Potter v. Meier, 338 F. Supp. 1353 (D. N. Dak. 1972) (delegate selection to national political convention), including foreign affairs pohitical question cases. See, e.g., Mottola v. Nixon, 464 F.2d 178 (9th Cir. 1972) (allegation of illegahty of American involvement in Southeast Asia as grounds to cancel plaintiff's orders to go to Vietnam); Kelley v. Société Anonyme Belge D'Exploitation, 242 F. Supp. 129 (E.D.N.Y. 1965) (whether Belgium's procedure constituted ratification of Warsaw Convention). The ineffectiveness exists in part because certification hes within the unfettered discretion of the trial judge. While there are instances in which district courts have resolved an issue, yet nevertheless "switched hats" ably and recognized that its resolution was sufficiently debatable that the decision should be certified, see Mottola v. Nixon, 464 F.2d at 182; Potter v. Meier, 338 F. Supp. at 1357, it is unreahistic to expect that virtually every foreign affairs matter will be so certified. Indeed, recent experience fails to bear out the hypothesis that at least in cases in which there was no doubt that the order, if erroneous, might harm the national 
In order to avoid these harms in an efficient way, this Comment suggests enactinent of the following proposed statute: ${ }^{150}$

Be it enacted, That a civil action filed in a United States district court in which the Governınent, either as a party or as amicus, claims nonfrivolously that the action, or an issue in the action, is a foreign affairs matter, inquiry into which is barred by a judicial nonintervention doctrine, shall be certified as a whole, or on the issues so challenged, to the appropriate United States court of appeals which shall determine as a matter of law whether a judicial nonintervention doctrine apphes to such case or issues: Provided, that such claim must be made within ten days of service of process.

(a) Certification shall stay all proceedings in the district court, including discovery.

(b) No prehminary injunction or other temporary relief shall be ordered before or during certification of the case.

(c) The court of appeals decision may be challenged by a petition for a writ of certiorari to the United States Supreme Court. However, the court of appeals may, at any time after its decision, permit discovery and other pretrial matters to resume im the district court.

\section{A. The Use of Three Appellate Judges is Proper}

It may appear surprising that the proposed statute requires three judges to look at a foreign affairs issue or case before the district court can consider its merits. If one judge inakes erroneous decisions, wouldn't three do the saine?

This Comment does not argue that all judges give too much weight to the protection of imdividual interests, or that any do so imtentionally, but rather that because of judicial training, orientation, and experience, a judge might incline toward the individual interest where the law is as

interest, judges will virtually always certify it. In Goldwater, Narenji, and Haitian Refugees, the district court did not certify its determination that the foreign affairs matters raised could be aired and decided, as inportant and controversial as the decisions were in those cases. One reason for this, most likely, is the saine reason that $\S \mathrm{I} 292$ is used infrequently in other types of cases: Certification can appear to be a concession by the district court that it is not sufficiently able or energetic to tackle the certified issue successfully.

Although the harms threatened by an airing or initial erroneous decision of the merits of foreign affairs cases seein to present an "extraordinary" circuunstance, soune courts have suggested that the legislative history of $\S 1292$ indicates that "extraordinary" means "avoiding extraordinarily protracted and expensive litigation." E.g., United States Rubber Co. v. Wright, 359 F.2d 784, 785 (9th Cir. 1966). Protracted and expensive litigation is not the harin threatened by district courts erroneously airing and deciding foreign affairs matters.

150. Congressional power to enact such a statute is not in doubt. $C$. Buckley v. Valeo, 424 U.S. 1, 8 (1976) (procedures under 2 U.S.C. $\$ 437$ h(a) (1970 \& Supp. IV) calling for unandatory certification of all challenges to constitutionality of Federal Election Cainpaign Act).

Compare the proposed statute with 5 U.S.C. $\$ 553$ (a)(1) (1976) (reinoving inatters raised in a "foreign affairs function" of the government froin the requirements of the Administrative Procedure Act, thereby placing them outside of the jurisdiction of the admimistrative law judge). 
unclear, often inherently so, as it is in foreign affairs. Thus, the substantive law of the foreign affairs nonintervention doctrines may be left unchanged but the number of judges who inust concur before a foreign affairs case can be tried on the merits should be increased. ${ }^{151}$ Since the three-judge district court has presented so many operational problems, the proposal uses the normal federal judicial structure to ensure threejudge examination and assessment.

\section{B. The Risks of the Proposal}

\section{Possible Deprivation of Individual Rights}

Application of a nonintervention doctrime has the effect of impeding judicial inquiry into acts that may infringe constitutional rights. The proposal, liowever, does not affect the principle that, even in foreign affairs cases, the judiciary must be willing to intervene if concerns for the national interest do not excuse or outweigh the resultant imfringement of constitutional rights. ${ }^{152}$ This proposal inerely requires that this decision be made by a panel of appellate judges or by the Supreine Court ${ }^{153}$ rather than by a simgle district court judge.

Admittedly, this proposal inay produce occasional delays in the vindication of constitutional rights. It will take some time for the court of appeals to decide the nonintervention issue, during which the plaintiff must wait. However, the gravity of the hanns that occur because of frequent initial erroneous decisions substantially outweighs the temporary deprivation of individual rights. Such factors as the likelihood of an expedited appeal of a foreign affairs ruling ${ }^{154}$ and the improbability that the plaintiff would ultimately prevail ${ }^{155}$ reinforce this conclusion.

151. The district court decisions in Goldwater and Narenji "Inay have turned in the first place on the individual quirks of individual judges in individual and very different cases." Barbash, The Explosion of Judicial Power, S.F. Chronicle, Feb. 10, 1980, Sunday World section, at 24, col. 1.

152. See, e.g., Afroyiun v. Rusk, 387 U.S. 253, 257 (1967) (Congress cannot take away citizenship without the citizen's assent). See also Gilligan v. Rhodes, 423 U.S. 1, 11-12 (1973) (conduct and training of National Guard not always beyond scope of judicial review); Tigar, supra note 26, at 1159 (decisions of military tribunals reviewable on habeas corpus).

153. It might be argued that decision of judicial nonintervention in foreign affairs cases by the Supreme Court rather than the courts of appeals is inore consistent with historical and functional considerations. See generally C. WARREN, THE Supreme Court IN UNITEd STATes History (1947). The Supreme Court has "a high sense of strategy and tactics," Scharpf, supra note 26, at 353 (quoting E. Rostow, The Sovereign Prerogative 34 (1962)), both from its constitutional position at the apex of the judicial system and its constitutionally granted status as a check on the political branches, and from its position as the only court that effectively controls its own docket. However, a proposal for inandatory certification directly to the Supreme Court would be too great a burden on the Court's resources.

154. Recent foreign affairs cases in the D.C. Circuit have been consistently expedited and the tinie lags have been brief. For exainple, in Narenji the interval between the district court ruling and reversal on appeal was 16 days. See note 8 supra. In Goldwater, it was about six weeks. See note 7 supra.

155. Since Youngstown Sheet \& Tube Co. v. Sawyer, 343 U.S. 579 (1952) (seizure of steel 
It is certainly possible to imagine a case in which the unavailability of an injunction, even for a short time, would greatly harm vital constitutional interests. Such a case, however, has not arisen in recent years. ${ }^{156}$

Such a case would present the liardest test for the proposed statute. For example, suppose a situation similar to that presented in Korematsu $v$. United States, ${ }^{157}$ in which the federal government ${ }^{158}$ decides to round up and confine all citizens and noncitizens whose ancestors came fron 1 a country with which the United States is at war. If an individual internee files suit challenging his confinement on substantial constitutional grounds, the United States would be likely to ask for certification of the case to the court of appeals. The foreign affairs nonintervention defense would not be frivolous because of the belligerency of the internee's alleged nation of allegiance toward the United States; thus, the district court should probably certify the case.

Given the importance of the claim, the appellate court would be likely to expedite the appeal. The Supreine Court would also be likely to act quickly. ${ }^{159}$ Thus, if the ultimate decision were that the courts should hear the case on the merits, any eventual relief would have been delayed only by a few weeks. ${ }^{160}$ Although this hypothetical is chosen

mills by President Truinan), the ultimate decision in a case that has an arguably serious impact on foreign affairs has virtually never gone against the Government, and "the few celebrated cases [that did] were often announced after the einergency that gave rise to the violation had passed." Scharpf, supra note 26, at 584. See Duncan v. Kahanainoku, 327 U.S. 304 (1946) (Court disapproved war-time suspension of constitutional rights in Hawaii affer the war was won); Ex parte Milligan, 71 U.S. (4 Wall.) 2 (1866).

The problem of later review in foreign affairs cases raises another set of issues. For example, suppose that two widows file suit against the Governinent seeking damages for alleged negligence that caused the wrongful deaths of their spouses. The first seeks to show that the recent raid in Iran to free the hostages was poorly and rashly planned and negligently conducted. Under the proposal set out here, her suit would be a foreign affairs case that the district court would have to certify.

In the second case, the plaintiff makes similar allegations, but the underlying raid is the one in Cambodia in 1975 to free the crew of the S.S. Mayaguez. In that case, the Government might not elect to assert a nonintervention doctrine. Even if it did, a court could rule that the assertion was frivolous due to the lapse of time and the changes in the Cambodian (now Kampuchean) governments. $C f$. Bernstein v. Van Heyghen Freres, S.A., 163 F.2d 246 (2d Cir.) (government that post-World War II inquiry would appear likely to embarrass was the extinct and universally discredited Third Reich), cert. denied, 332 U.S. 772 (1947).

156. The most recent occurrences of such a case were Korematsu v. United States, 323 U.S. 214 (1944) (Japanese relocation during World War II), and Duncan v. Kahanamoku, 327 U.S. 304 (1946) (internees under Hawaiian inartial law).

157. 323 U.S. 214 (1944).

158. If a state governınent makes this decision, the federal governinent probably would not assert that it involves a foreign affairs matter. Thus, this proposal would not apply.

159. See Remarks of Chief Justice Burger, before Alnerican Bar Association, San Francisco (August 14, 1972): "There are adequate means to secure an expedited appeal to the Supreme Court if the circumstances genuinely require it," reprinted in [1976] U.S. CODE CONG. \& AD. NEws 1988, 1990.

160. By comparison, interjurisdictional certification-federal court certification of a close, 
as an extreme case, the overall balance is still in favor of the proposal's adoption. $^{161}$

\section{The Proposal Would Not Waste Judicial Resources}

The proposal should not increase the burdens on judicial resources. When the procedure results in avoiding a hearing and subsequent appeal on the merits, judicial resources will have been conserved. Furthermore, due to the lesser need for the time-consuming consideration of motions for stays, ${ }^{162}$ the proposal may lessen the burden on appellate courts.

It might be argued that the proposal is so open-ended that it would permit the foreign affairs nonintervention doctrines to swallow up the rule of judicial review. Artful pleading, it might seein, could show a comiection between any sigmificant act of Congress or the President and foreign affairs. ${ }^{163}$ This proposal, however, does not call for the dismissal of cases that would not have been dismissed, im any event, on appeal. It simply provides for a faster determination of whether cases imvolving foreign affairs should be dismissed.

Moreover, the proposal contains three important limitations: 1) a requirement that it be the Government, whether as a party or as amicus, that states that a particular case imvolves foreign affairs; 2) a nonfrivolousness threshold for the district court; and 3) appellate review of the decision. The second limitation is meant to be the least significant, since much of the point of this proposal would be lost if the district court were to inquire aggressively into the foreign affairs nexus of the case in making its decision concerning certification. In those instances in which the first limitation is subverted-i.e., when the Administration uses the foreign affairs claim in order to cover up its transgressions out of a fear of doinestic repercussions ${ }^{164}$ _appellate review should serve to

controlling question of state law to the highest court of the state-has worked well. It "can normally produce a definite statement of state law without excessive delay or burdens for the court or litigants." Note, Scope of Certification in Diversity Jurisdiction, 29 RuTGERS L. REv. 1155, 1175 (1976). Federal-federal certification should work at least as well as federal-state certification.

161. Cf. Baltimore Contractors, Inc. v. Bodinger, 348 U.S. 176, 185 (1954) (dictum) (generalizations as to efficiency of imterlocutory appeals difficult to make); United States v. American Tel. \& Tel. Co., 567 F.2d 121, 133 (D.C. Cir. 1977) (explaining that complicated procedure ordered for production of documents was worth the delay it would cause).

162. See Leventhal, Appellate Procedures: Design, Patchwork, and Managed Flexibility, 23 U.C.L.A. L. REv. 432, 442 (1976).

163. Cf. Halperin v. Kissinger, 606 F.2d 1192, 1201 (D.C. Cir. 1979) (wiretaps of former member of National Security Council staff) (claimed national security justification rejected).

164. "[D]omestic repercussions, einbarrassinent to the officials involved, or administrative inconvenience unconnected with any foreign policy interest should not enter into the calculus" of deciding whether the "foreign affairs functions" exception to the APA, see note 151 supra, is applicable. Comment, supra note 26, at 421. See also Bonfield, Military and Foreign Affairs Function Rule-Making Under the APA, 71 Mich. L. Rev. 221, 258-70 (1972). 
expose the "cover-up." In many other cases this limitation will be significant. For example, the Government has on occasion represented to the courts that application of the Act of State doctrine would not advance the interests of American foreign policy. ${ }^{165}$ It has also left to the courts the responsibility for deciding whether ships owned or operated by foreign governments are immune from suit during peacetime. ${ }^{166}$ In addition, the Government may often be eager for a judicial determination of the inerits of a case, whether to buttress a rule of imternational law, ${ }^{167}$ or to impede a state's atteinpt to inject itself into the conduct of foreign affairs. ${ }^{168}$ And even if the choice is between an occasional erroneous district court decision that causes the harms described in this Coinment and an occasional certification that merely delays the exposure of an attempt to cover up Adninistration transgressions, the public interest strongly favors a procedure that permits the latter, but not the former.

\section{Stays of Discovery are Necessary}

Even if the proposal is otherwise meritorious, is it necessary to stay discovery in all cases, even in those not involving disclosure of state secrets? There are two responses. First, in virtually all cases the defendant will refuse to comply with discovery requests on the basis of the alleged foreign affairs sensitivity of the evidence sought to be discovered. In sucl a situation, the court, unless discovery has been stayed, inust impose sanctions on the recalcitrant party. If that party is a foreign government or entity, imposition of discovery sanctions would in itself cause embarrassinent and/or cross-purposes harms. If that party is a branch or agency of the United States Government, such sanctions may also cause both types of harm. ${ }^{169}$ Rarely will a case

165. See First Nat'l City Bank v. Banco Nacional de Cuba, 406 U.S. 759, 768 (1972).

166. Scharpf, supra note 26 , at 577 n.214.

167. See, e.g., Filartiga v. Pena-Irala, No. 79-6090 (2d Cir. June 30, 1980) (Lexis). Dr. Filartiga and his daughter had been opponents of the Stroessner dictatorship in Paraguay. Before the Filartigas left Paraguay, Pena-Irala, the head of the police, had allegedly ordered their son to be tortured to death as a means of intinidating them. A criminal action against Pena-lrala filed in Paraguay was unsuccessful. The Filartigas, now in the United States, learned that Pena-Irala was also in the United States and brought a civil action against hin in federal court. The district court, agreeing that there was probably ennerging universal acceptance that official deliberate torture violates international law, ruled, however, that the case fell into an exception to judicial inquiry by an Ainerican federal court: it involved a foreign State's treatment of its own citizens. Therefore, the court disinissed for lack of subject inatter jurisdiction. On appeal, the Departments of Justice and State appeared as amicus curiae arguing that deliberate torture of anyone, perpetrated under color of official authority, violates universally accepted norms of the international law of human rights. The court of appeals agreed and reversed.

168. The Governinent asked to intervene on the side of several hundred Iranian students seeking to dcclare unconstitutional a Mississippi law that would force Iranian students to pay five times as unuch tuition as other students. Wash. Post, June 22, 1980, at A5, col. 1.

169. Sanctions would embarrass the branch or the agency, in turn embarrassing the govern- 
threaten only disclosure of state secrets harms.

Second, many disclosure situations may involve a direct conflict between an order of an American court and the pronouncement of a foreign government. ${ }^{170}$ Since the harms that result from a failure to order a stay in a case involving foreign affairs are substantial, a stay of proceedings should be accompanied by a mandatory stay of discovery rather than a continuation of normal discovery procedures or resort to confidentiality orders ${ }^{171}$ and similar devices.

\section{CONCLUSION}

American jurisprudence has long and correctly recognized that foreign affairs and intergovernmental relations differ from domestic affairs. The main point of difference for the judicial branch is that in foreign affairs cases the potential harms from independent judicial review of legislative and executive decisions are particularly significant. Although judicial recognition of that difference has been expressed under many doctrinal and conceptual names-extreme deference to decisions concerning war, national defense, immigration and naturalization, sovereign immunity, Act of State, and particularly the political question doctrine-these doctrimes can be organized around three kinds of harin to the national interest: embarrassment, cross-purposes, and state secrets disclosure. These harms can occur from any hearing on or initial erroneous decision of the merits of a foreign affairs decision, not only from an ultimate erroneous decision to interfere with such a decision. However, doctrinal and institutional factors impede consistently correct district court decision of foreign affairs matters.

This Comment suggests a statute requiring mandatory district court certification of a foreign affairs matter before it can be aired in court or decided on the merits. The proposed statute addresses the problem of the harm caused by an initial erroneous decision, a harm that ultimate judicial imvocation of a foreign affairs nonintervention doctrine does not of its own force prevent. The statute is not aimed at

ment. Sanctions might also cause cross-purposes harm, if they forced disclosure of information that caused America's allies to cooperate less in the pooling of intelligence, or if they inhibited intelligence-gathering activities and procedures. See generally Hayden v. National Sec. Agency/Cent. Sec. Serv., 608 F.2d 1381, 1385 (D.C. Cir. 1979) (nation has legitimate interest in secrecy).

170. See, e.g., In re Westinghouse Elec. Corp. Uranium Contracts Litigation, 563 F.2d 992 (10th Cir. 1977) (reversing district court, which had held corporation in criminal conteunpt for refusing to produce records stored in Toronto, since production could have resulted in criminal prosecution in Canada, and Canadian government refused consent to allow production).

171. For a discussion of the advantages and disadvantages of confidentiahty orders in general, see Dore, Confidentiality Orders-The Proper Role of the Courts in Providing Confidential Treatment for Information Disclosed Through the Pre-Trial Discovery Process, 14 N. ENG. L. REv. 1 (1978). 
changing the substantive contours of any of the nonintervention doctrines. It does seek to avoid the very substantial harms to the national interest that result from a single judge's misapplication of those contours. The entire nation has an interest in achieving that goal.

David A. Katz*

* A.B. 1976, University of California, Berkeley; J.D. 1980, Boalt Hall School of Law, University of California, Berkeley. 